\title{
Cursed Resources? Political Conditions and Oil Market Outcomes*
}

\author{
Gilbert E. Metcalf \\ Tufts University and NBER \\ Catherine Wolfram \\ UC Berkeley and NBER
}

March 2012

\begin{abstract}
We analyze how a country's political institutions affect oil production within its borders. We find a pronounced negative relationship between political openness and volatility in oil production, with democratic regimes exhibiting less volatility than more autocratic regimes. This relationship holds across a number of robustness checks including using different measures of political conditions, instrumenting for political conditions and using several measures of production volatility. Political openness also affects other oil market outcomes, including total production as a share of reserves. Our findings have implications both for interpreting the role of institutions in explaining differences in macroeconomic development and for understanding world oil markets.
\end{abstract}

\footnotetext{
* Metcalf: Department of Economics, Tufts University and NBER, gilbert.metcalf@tufts.edu; Wolfram: Haas School of Business, UC Berkeley, and NBER, wolfram@haas.berkeley.edu. We are grateful to Carla Peterman for extraordinary research assistance and to Daron Acemoglu, Arthur van Bentham, Ryan Kellogg, Lutz Kilian, Richard Schmalensee, Enrico Spolaore and seminar participants at the University of Chicago Harris School, Columbia University, University of California Berkeley, Duke University and University of Michigan for helpful comments.
} 


\section{Introduction}

Development levels vary considerably across countries, and explaining why these differences exist is one of the central questions in economics. While scholars have long hypothesized that political institutions play an important role (see, e.g., North 1981), a recent literature has made progress identifying a causal impact of institutions on cross-country differences in macroeconomic outcomes. ${ }^{1}$ Still, the mechanisms by which specific institutions affect economic outcomes remain a "'black box"” (Acemoglu, Johnson and Robinson, 2001 hereafter AJR - p.1395). ${ }^{2}$

This paper focuses on the influence of institutions on one particular industry: crude oil production. We document a pronounced negative effect of good political conditions on volatility in oil production, and this result is robust to using several different measures of political conditions. We also address the potential endogeneity of political structure, as suggested by the literature on the "resource curse." We estimate two-stage least-squares regressions where we instrument for recent political institutions using institutions before oil was commercialized. We find that the negative relationship persists in these specifications. We also evaluate whether other macroeconomic differences across countries affect oil market outcomes, including financial openness and legal formalism. None of these factors has a significant effect on volatility once we control for institutions.

It is important to acknowledge that a country's oil production may not necessarily be inefficient if it is volatile. To allow for this, we also construct volatility measures that control for market factors which should drive changes in a country's oil output, and our results are robust to using these alternative measures. ${ }^{3}$

Ideally, we would also like to measure oil output controlling for the natural resources available to the country, as this is analogous to studies that examine factors contributing to differences in economic development. With this goal in mind, we also examine the link between political institutions and a country's average production as a share of its proven reserves. We

\footnotetext{
${ }^{1}$ See Barro (1997), Hall and Jones (1999), Rodrik (1999), Acemoglu, Johnson, Robinson and Thaicharoen (2003), Perrson and Tabellini (2003), and Mulligan, Gil and Sala-i-Martin (2004) for varying perspectives on the influence of political institutions on economic outcomes.

${ }^{2}$ Acemoglu and Johnson (2005) provides a peek inside the box, finding evidence that firms in countries with poor political institutions are more likely to report concerns about government corruption, including "additional payments" for government services, and concerns about unpredictable government regulation.

${ }^{3}$ Existing work considers the effect of political institutions on macroeconomic volatility. See, for example, Acemoglu, Johnson, Robinson and Thaicharoen (2003).
} 
find that countries with better political institutions produce a higher share, although we devote less attention to these results since the data on reserves are self-reported in some cases and could be systematically biased. Finally, we show that political institutions lead to volatility in the number of active wells, suggesting that the volatility is less likely to be driven by physical characteristics of a country's oil fields.

Oil production provides a particularly convenient lens to view the possible microeconomic foundations for macroeconomic outcomes as oil is a commodity sold on a world market. This means that production decisions within a country should be driven by world demand and not local macroeconomic conditions. Was this not the case, our results would be less interesting as they could simply reflect the effect of political institutions on overall macroeconomic activity. Since oil demand is worldwide, however, we can be confident that our results reflect supply-side factors and not demand-driven output volatility.

Another reason that oil is well-suited to this analysis is that the unit of output (a barrel of oil) is of essentially homogenous quality and is consistently measured across countries. Finally, rich data are available on oil production and its determinants, such as reserves and the number of wells.

By documenting that political institutions affect outcomes in a particular industry, our results provide insight on how institutions affect aggregate economic output. For example, they suggest that while political institutions may work by influencing structural factors, such as by promoting a well-developed commercial sector or less reliance on agriculture (see, e.g., Duarte and Restuccia, 2010), these cannot be the only mechanisms at play as institutions have effects within an industry. Although our results cannot address this hypothesis directly, they are consistent with the idea that well-functioning political institutions support efficient investment in crude oil production and prevent wars, domestic conflicts and nationalization episodes, which can severely limit a country's oil production capabilities. We support this interpretation with a detailed analysis of nearly 150 episodes when countries' oil output fell significantly. This analysis strongly supports the conclusion that poor political institutions undermine production, and provide insight on the mechanisms leading to the production declines.

Our results also provide insight on world oil markets. Like many energy markets, oil markets are characterized by extremely inelastic short-run supply and demand, meaning that even small fluctuations in either can lead to large swings in price. While much has been written 
about how systematic shifts in oil demand or supply affect prices (see, for example, Hamilton (2009) and Kilian (2009)), less is understood about the underlying determinants of short-run changes in supply.

Our results imply that political institutions in the countries endowed with oil reserves affect the volatility, and perhaps the level, of its production. To the extent countries with poor political conditions will have less stable production of other natural resources, our results suggest a useful metric for comparing different energy sources. As U.S. policymakers attempt to drive shifts to new, alternative energy technologies, it is useful to be able to make these comparisons.

To explore the implications of our results for world oil markets, we construct annual, worldwide statistics that summarize the political institutions of oil-producing regimes. Generally, our indexes depict a reduction in the political conditions of oil producing countries between 1965 and 1978, followed by an increase that peaks sometime in the late 1990s or early 2000s, depending on which index is considered. In recent years most of the indexes show a modest decline starting around 2003.

We next decompose the measures into "production share" and "internal conditions" indexes to show how changes in the aggregate measures are driven by changes across countries in their share of world oil production and changes within countries in political conditions. In the early part of our sample, changes in oil political conditions were mainly driven by changes in the production share, as Middle Eastern countries accounted for a larger and larger share of total production. Recent trends, however, appear to be driven by changes in internal conditions in addition to changes in the location of oil production.

We show that the higher the share of oil coming from countries with poor political conditions in any given year, as measured by the decomposed "production index," the higher is the volatility of oil prices in that year. Within-country changes in political conditions, as measured by the decomposed "internal conditions index," if anything have the opposite effect on oil price volatility, suggesting that it may take time before short-run changes in political conditions impact oil production.

While short-run production volatility within one country's borders may be quickly counteracted by adjustments in other countries so that any resulting price volatility will be shortlived, there are reasons to be concerned about the volatility. For one, price volatility makes business planning difficult and raises the cost of hedging risk. It is particularly difficult for 
energy-dependent industries such as the airlines and automakers. It also raises concerns for many that speculation is contributing to price volatility and spikes causing many to call for tighter regulation of energy markets. ${ }^{4}$ Finally, we test whether countries with poor political conditions are more likely to cut back on oil production when prices are high and/or other countries are also cutting back.

The next section of the paper discusses the mechanisms by which political conditions might affect oil markets. Section III presents our main empirical findings, documenting the negative relationship between political conditions and oil market volatility. Section IV interprets our findings and analyzes their implications for price volatility in world oil markets. We also discuss why our findings probably do not support an "energy-security" based argument for government intervention in energy markets. We conclude in section V with some thoughts on the lessons to be drawn from this analysis as well as possible future extensions of this research agenda.

\section{Background}

In this paper we seek to identify the role that political conditions play in driving the volatility of oil production. While a considerable literature exists on the causal relationship between a country's oil wealth, or wealth from other natural resources, and political governance (the "resource curse" literature), there has been little focus on the role governance plays in affecting supply. We discuss the resource curse literature in this section both to distinguish our paper from that line of research and to motivate the econometric strategy we use in the next section.

A number of papers have analyzed the relationship between a country's resource wealth and various economic and political outcomes, including slower economic growth and development, conflict, and corruption. We focus on the subset of papers that argue that "oil and mineral wealth tends to make states less democratic" (Ross (2001), p. 328). Ross (2001) identifies three causal mechanisms: governments keep tax rates low and spending high to dampen support for democracy (a rentier effect); they spend money on police to repress dissent (a repression effect); and they fail to develop a modern economy with industrial and service jobs thereby preventing the rise of a middle class that might demand greater voice in government (a

\footnotetext{
${ }^{4}$ The Commodity Futures Trading Commission announced plans to consider placing limits on the trading behavior of financial investors in futures markets for energy products. The CFTC opened hearings in July 2009 to consider how this might be best accomplished. See Andrews (2009).
} 
modernization effect). Haber and Menaldo (2008) find support for a resource curse of the sort articulated by Ross in simple pooled time-series cross-section regressions but they find the results are sensitive to the inclusion of fixed effects. See also the recent empirical analysis by Wacziarg (2009). For our purposes, these three papers (and others such as Smith (2004), Basedau and Lacher (2006), Tsui (2008), and Alexeev and Conrad (2009)) highlight the point that we cannot treat political institutions as exogenous in any analysis of the role political conditions play in affecting oil supply, and they motivate our choice of instruments for a country's political conditions.

Turning to the effect of institutions on energy markets, Bohn and Deacon (2000) consider how ownership risk affects the exploitation of natural resources in countries. They find that higher ownership risk decreases oil drilling and oil production whereas higher risk increases deforestation. Ownership risk affects oil and forestry differently due to differential capital intensity. While ownership risk encourages more rapid exploitation to extract resources before assets are (potentially) expropriated by the government, capital investment required to extract resources is also discouraged. Since oil production is relatively capital intensive (compared to forestry) this investment effect offsets the production effect. Our paper differs from Bohn and Deacon in several important respects. First, while they interpret weak institutions as indicative of "ownership risk," in one specification, we include a variable that measures expropriation events in addition to the political conditions variable. The results of this specification suggest that political conditions affect oil production more through other channels (e.g., government pressures to pursue nonmarket goals) than through expropriation risk, although this is based on only one, perhaps blunt, measure of ownership risk. Second, we treat governance institutions as endogenous and instrument for them in our empirical analysis.

This brief literature review makes clear a couple of key points. First, political conditions are endogenous and likely to be influenced by the existence and characteristics of oil markets in the country. Second, other factors impact both political conditions and oil market production. Unless we control for these factors, we are likely to mismeasure the relationship between governance and oil production conditions. In the empirical work that follows, we attempt to tease out the causal impacts of governance structures on oil production volatility while controlling for a number of these confounding influences that are likely to be correlated with both polity and oil production. 


\section{Empirical Analysis}

We analyze the empirical relationship between a country's political conditions and its oil production in several steps, first presenting our basic results on political conditions and volatility, then describing our approach to dealing with the possible endogeneity of political conditions, next testing the empirical relationship using several additional political conditions measures, and finally presenting several alternative specifications that evaluate whether other macro factors influence volatility in addition to political institutions. We also show results suggesting that political conditions influence the share of a country's reserves that are extracted, although we place less emphasis on these results since reserve estimates could be misleading. Table 1 provides summary statistics on all of the variables used in the analysis.

Our basic regression is of the form:

$$
\mathrm{V}_{\mathrm{i}}=\alpha_{1}+\beta_{1} \mathrm{PC}_{\mathrm{i}}+\mathbf{X}_{\mathrm{i}} \gamma_{1}+\eta_{\mathrm{i}}
$$

where $\mathrm{V}_{\mathrm{i}}$ is a measure of oil volatility in country $\mathrm{i}, \mathrm{PC}_{\mathrm{i}}$ is a measure of political conditions, $\mathbf{X}_{\mathbf{i}}$ is a vector of control variables included in some specifications and $\eta_{i}$ is a random error. We estimate equation (1) across the 48 major oil-producing countries. All our specifications are weighted by a country's average production within the appropriate time period, although the basic results are not sensitive to this weighting. ${ }^{5}$ The scale of oil production varies dramatically across the countries in our database (from 2007 production of 10,400,000 barrels per day in Saudi Arabia to 82,000 barrels per day in Cameroon and 98,000 barrels per day in Tunisia). We are concerned that variance, our dependent variable, is more likely to reflect measurement or data error for the smaller countries. For example, if in all countries, the last digit of the reported figure was generated randomly due to measurement error, the variance for the smaller countries would capture more of this noise. This is not classical measurement error as it will vary systematically by observation. To avoid bias introduced by systematic differences in scale, we weight by production.

Our base measure of political conditions is the Composite Democracy Index from the 2007 Polity IV Project. ${ }^{6}$ The composite score is defined as the difference between the Institutionalized Democracy index $\left(D E M O C_{i t}\right)$ and the Institutionalized Autocracy index

\footnotetext{
${ }^{5}$ For example, without weighting, the first row of Table 2 yields a coefficient of $-.0056^{* *}(.0020)$ in the first column and $-.0043^{* *}(.0020)$ in the second column.

${ }^{6}$ The Polity IV data are described in detail in Marshall and Jaggers (2009) and are available on-line at http://www.systemicpeace.org/inscr/inscr.htm.
} 
$\left(A U T O C_{i t}\right)$. The former index is based on the competitiveness and openness of executive recruitment, constraints on the chief executive, and competitiveness of political participation. The index ranges from zero to ten. The autocracy index is based on other measures of competitiveness and openness of executive recruitment, constraints on the chief executive, and competitiveness and regulation of political participation. It also ranges from zero to ten. The resulting combined polity score ranges from -10 (strongly autocratic) to +10 strongly democratic. For use in our index decompositions in Section IV, we rescale the index to range from 1 to 21 with higher values still indicating stronger democratic tendencies. Country-level oil production data is from BP (2009). ${ }^{7}$

\section{A. Basic Results}

Table 2 presents versions of equation (1) estimated over two different time periods and without covariates. We use data from both 1965-2007, where the start date is constrained by the availability of the oil production data, and 1980-2007, where the start date is constrained by the availability of data on oil reserves, used in later rows of the table. Other work on political institutions has begun with the 1970s to ensure that the countries are independent nation states throughout the entire period of analysis (Acemoglu, Johnson, Robinson and Thaicharoen, 2003).

The results in the first row suggest that countries with higher polity scores have lower volatility, and the coefficient estimate is similar across the two different time periods. Considering the specification in the left-hand column, the magnitude of the coefficient on polity suggests that moving a country from the $25^{\text {th }}$ percentile polity score of 4.1 (e.g., Libya or Vietnam) to the $75^{\text {th }}$ percentile polity of 16.4 (e.g., Thailand or Ecuador), should reduce production volatility by .084 , which represents approximately half a standard-deviation change in volatility. Also, the $\mathrm{R}^{2}$ in that specification suggests that political conditions explain nearly one fifth of the volatility differences across countries. Figure 1 plots the data used to generate this set of results, where the size of each circle is proportional to the country's average production over the sample period.

We also measure volatility in oil production after controlling for changes in underlying market conditions. For example, if a country's oil production increases dramatically over the

\footnotetext{
${ }^{7} \mathrm{We}$ dropped country-year observations when production less than 5 percent of average production in the country, so that production ramp-ups, such as in the UK, did not influence our results. Also, in 1985 and later, BP reports individual production for Russia, Kazakhstan, Azerbaijan and Tajikistan. We allocated pre-1985 Soviet production to those four countries in proportion to their late 1980s production. Our results are not sensitive to this decision and are almost identical if we ignore the Soviet period or use different allocation rules for the Soviet production.
} 
span of several years because of the discovery of new oil reserves, this would be considered appropriate, economically-motivated volatility. Similarly, profit-maximizing firms within a democratic country may cut back on production if world demand declines.

To separate the "excess" volatility from the market-driven changes in oil production, we consider the following formula:

$$
\ln \left(Q_{i t}\right)=f\left(S_{i t}, D_{i t}\right)+g\left(P C_{i t}\right)
$$

where $Q_{i t}$ represents country i's production in year $t, f\left(S_{i t}, D_{i t}\right)$ reflects output driven by both supply $(S)$ and demand $(D)$ factors, $g\left(P C_{i t}\right)$ captures the influence of political conditions $(P C)$ on output

We either estimate or calculate $\ln \left(\hat{\mathrm{Q}}_{\mathrm{it}}\right)=\hat{\mathrm{f}}\left(\mathrm{S}_{\mathrm{it}}, \mathrm{D}_{\mathrm{it}}\right)$ and then calculate the residual production: $\hat{g}\left(\mathrm{PC}_{\mathrm{it}}\right)=\ln \left(\mathrm{Q}_{\mathrm{it}}\right)-\ln \left(\hat{\mathrm{Q}}_{\mathrm{it}}\right)$. Our country-level measure of volatility is then:

$$
\mathrm{V}_{\mathrm{i}}^{1}=\operatorname{std} \cdot \operatorname{dev} \cdot\left(\hat{\mathrm{g}}\left(\mathrm{PC}_{\mathrm{it}}\right)-\hat{\mathrm{g}}\left(\mathrm{PC}_{\mathrm{it}-1}\right)\right)
$$

The second row of Table 2 reflects a specification where $f()$ is an estimated countryspecific quadratic time trend. At the field level, petroleum engineers have long understood that production will increase slowly at first, then more quickly and eventually decline (Hubbert (1956)). For some of our countries, output is dominated by a handful of fields, so this relationship may hold at the country level. Because some countries began extracting oil long before the beginning of our dataset while others began during our dataset, we are concerned that the volatility measure might reflect changes in output driven by petroleum engineering factors, as countries with recent oil discoveries would go through both the slow and rapid increase in our data set. The results in the second row suggest that controlling for this possibility, the relationship between polity and volatility is even stronger, and, in the 1981-2007 time period accounts for almost half of the variation in volatility. ${ }^{8}$

The third and fourth rows of Table 2 calculate $f()$ using information on world GDP, which affects world oil demand, and a country's reserves, which, as an abstraction, we take to be exogenous determinants of the country's ability to produce oil. ${ }^{9}$ The reported specifications reflect a coefficient of one on both $\ln$ (World GDP) and $\ln$ (Reserves), although the results are

\footnotetext{
${ }^{8}$ These results do not appear to reflect over-differencing as they are very similar to results using the standard deviation of the residuals from the quadratic trend as opposed to the difference in the residuals.

${ }^{9}$ We have also estimated specifications using Kilian (2009)'s real demand variable, as he argues that it is a much better predictor of commodity demands than world GDP. The coefficient on polity was slightly smaller in absolute value, although still precisely estimated to be different from zero.
} 
quantitatively very similar if we impose different coefficients on either variable. ${ }^{10}$ In both rows, the absolute value of the coefficient on polity declines, but remains statistically significant at the five-percent level.

Finally, the last row of Table 2 reports coefficient estimates that use a dependent variable measuring the largest single percent decline in annual production. The results similarly suggest that countries with poor political conditions are more prone to large output drops. In the regressions that follow, we will report results based on the volatility measure used in the first row of Table 2, although our results are not sensitive to this decision.

\section{B. Reverse Causality}

We argued in section II that our polity measure is likely endogenous and possibly correlated with the error term in regression equation (1). In Table 3 we report results using instrumental variables specifications. We assume that activities that took place before oil was commercialized in a country will reflect institutions independent of oil. The results in the second column use the polity measure before known commercialization, where we use a broad definition of known commercialization, dating it as the first year we see oil production in our data base unless we were able to find evidence of earlier commercialization in a PennEnergy's Worldwide Oil Field Production Survey or in Alexeev and Conrad (2009). ${ }^{11}$ The results in column three use a narrower definition, dating commercialization based only on outside sources.

The pre-commercialization instruments are valid if polity measures are persistent over time. In that case, the instruments will be correlated with the time-persistent components of the polity measures while post-commercialization impacts of oil on polity are uncorrelated with the instruments. In both cases, the first-stage coefficients are positive as expected and the F-statistics suggests that the instruments have good explanatory power.

Both instruments are only available for a subset of our countries. The broad polity variable is missing for Indonesia and Qatar, while the strict polity information is missing primarily for African and Asian countries. OLS results based on the same subset of the data are reported in the panel below the 2SLS results.

\footnotetext{
${ }^{10}$ The equation we estimate is a reduced form of the supply and demand equations under certain assumptions about the relationship between income, supply and demand elasticities.

${ }^{11}$ The field-level data are described at: http://ogjresearch.stores.yahoo.net/worldwide-oil-field-productionsurvey.html. Unfortunately, field-level production was only available for a small subset of the observations.
} 
When we use the broad pre-commercialization polity instruments, the two-stage least squares result suggests a smaller impact of polity on volatility compared to the equivalent OLS specification. This could reflect a resource curse phenomenon if higher exogenous volatility in oil production facilitates more autocratic governments, perhaps because an autocrat is better able to smooth oil revenues over boom and bust periods. The results may be imprecise because the instruments are good at identifying whether countries end up with high or low polity scores but they do not pick up subtle differences across countries, which presumably provides additional power in the OLS results.

\section{Alternative Political Conditions Measures}

A similar story emerges when the polity variable is replaced by other measures of a country's internal political conditions. We consider four additional measures:

Freedom House Political Rights ( $P \boldsymbol{R}_{i t}$ ): Freedom House ranks countries on a variety of scales including political rights and civil liberties (next index). We use data from the 2008 Freedom House Survey. ${ }^{12}$ The political rights index is based on a checklist of ten questions that is converted to a seven point scale ranging from 1 (most political rights) to 7 (fewest political rights). For consistency with our other measures, we rescale the index to range from 1 (fewest political rights) to 7 (most political rights).

Freedom House Civil Liberties ( $\left.C L_{i t}\right)$ : Based on the answers to fifteen questions, a score between 1 (most civil liberties) and 7 (fewest civil liberties) is awarded. As with the civil liberties index, we rescale the index to range from 1 (fewer civil liberties) to 7 (most civil liberties).

ICRG Expropriation Risks: Finally, we use the two expropriation measures used in previous macroeconomic work on institutions. The first, capturing the risk of expropriation in a country between 1982 and 1995, was used by Acemoglu, Johnson and Robinson (2001), while the second composite index was used by Hall and Jones (1999).

Results are reported in Table 4. Each panel of the table reports univariate OLS and 2SLS specifications, equivalent to both the upper and lower panels of the second column of Table 3. The results for both of the Freedom House variables are very similar to those in Table 3, suggesting a negative relationship between production volatility and internal conditions in both

12 This database is available on-line along with a description of the methodology at http://www.freedomhouse.org/template.cfm?page=15\&year=2008. 
the OLS and 2SLS specifications, and all results are statistically significant at the ten percent level except for the 2SLS specification for the Freedom House Political Rights variable, which is significant at the $11 \%$ level. In fact, even though the Freedom House and polity variables are constructed using different methodologies, they are highly correlated $\left(\sigma_{\mathrm{FH} \text { Civil Liberties }- \text { Polity }}=0.95\right.$ $\sigma_{\text {FH Civil Liberties - Polity }}=0.92$ ).

Both ICRG measures are negatively and statistically significant predictors of oil production volatility, and this holds for both the OLS and 2SLS specifications.

For three of the four measures, the estimated coefficients in the 2SLS regression are smaller in absolute value than the OLS coefficients. The ICRG risk of expropriation is the one exception to this pattern. The first-stage coefficients are positive and significant in all four cases, although the F-statistic suggests weak explanatory power using the ICRG risk of expropriation.

\section{Additional Covariates}

Table 5 reports results that include variables that capture cross-country differences in additional, nonpolitical, determinants of development. Our objective is to discern whether the strong relationship between political conditions and oil market volatility is mainly capturing an intermediate relationship between political conditions and another factor, such as financial openness. We do this by estimating versions of equation (1) that include several additional covariates described more fully below (represented by Add. Cov.i below).

$$
\mathrm{V}_{\mathrm{i}}=\alpha_{2}+\beta_{2} \mathrm{PC}_{\mathrm{i}}+\delta_{2} \text { Add.Cov } \cdot \mathrm{i}+\mathbf{X}_{\mathrm{i}} \gamma_{2}+\mathrm{v}_{\mathrm{i}} .
$$

If there is an intermediate relationship between political conditions and the additional covariate, then $\beta_{1}$ from equation (1) will reflect both the direct effect of political conditions on volatility and the indirect effect, working through the covariate. Equation (4) will separately identify the direct effect, so if $\beta_{2}$ approximately equals $\beta_{1}$ from equation (1), this suggests that the relationship we have picked up so far is not due to an intermediate effect of political conditions on the additional covariate.

Panels A through D use Polity, Freedom House Political Rights, Freedom House Civil Liberties and the ICRG Composite Index, respectively. Each column in a panel reports results from a separate specification. All specifications include a control for the land area in a country (square miles) on the hypothesis that larger countries may be able to diversify production across sites and so control volatility. This hypothesis bears out as countries with larger land area appear to experience less production volatility. To save space, we do not report the coefficient on the 
land area variable, but in all specifications, it is negative and statistically significant at the five percent level or higher. ${ }^{13}$ The economic impact is small, though, as the coefficient suggests that volatility falls by one-fifth of a standard deviation in countries with four million square miles more land area, which is more than a one standard deviation change in land area among our countries. The first columns in Panels A-D, based on the same time period as the specification in the first row of the left-hand column of Table 2, only include the land area variable, and are included for purposes of comparison to the rest of the table. ${ }^{14}$

In the second column, we report results that include a measure of the country's financial openness: its gross stock of foreign assets and liabilities as a share of GDP. ${ }^{15}$ We include this variable to test the hypothesis that political institutions affect firms' ability to produce efficiently at least in part by altering their access to foreign capital. ${ }^{16}$ Also, previous work has pointed to the importance of financial openness at the industry level. For example, Rajan and Zingales (1998) show that manufacturing industries that are more dependent on external finance grow disproportionately faster in countries that are financially open. While that paper's focus on manufacturing startups may appear irrelevant to the oil extraction industry, startups may provide many valuable support services to established oil extraction firms.

If political institutions affect oil market outcomes by influencing the degree of financial openness, we would expect the coefficient on financial openness to be negative and the coefficient on polity to fall in absolute value. In fact, in all four panels, the coefficient on the financial openness measure is positive, suggesting that countries with more financial openness are more volatile. It is not significant at conventional levels, and the coefficient on the polity variable is attenuated, but not appreciably so. The raw correlation between polity and financial openness for our countries is -.076. This result could reflect the fact that even in countries with considerable capital flows, foreign investment in the oil industry is limited. It may also simply

\footnotetext{
${ }^{13}$ The reported coefficients in Table 5 are not sensitive to the inclusion of land area.

${ }^{14}$ We have also estimated specifications that control for the share of a country's production from offshore fields. Offshore wells are considerably more expensive than onshore wells, so countries with a larger share of offshore fields may be more likely to reduce production when prices decline. Though our variable is somewhat coarsely measured, we found no indication of a relationship between offshore fields and production volatility. See Appendix B for more details.

${ }^{15}$ The data are described in Lane and Milesi-Ferretti (2006), and Kose, Prasad, Rogoff and Wei (2006) summarize the pros and cons of different financial openness measures. We have tried other variables, such as the Chinn-Ito Index (see Chinn and Ito (2006), and they are similarly insignificant.

${ }_{16}$ The literature on the relationship between financial openness and growth has recognized the potential relationship between political conditions and financial institutions (see, e.g., Eichengreen, Gullapalli and Panizza (2009)).
} 
reflect the fact that countries with considerable oil wealth are diversifying by investing abroad (e.g., Saudi Arabia and other major Arab oil and gas producing states), which makes them appear more financially open.

The next set of specifications includes a dummy variable for countries that are in OPEC over the entire time period. Political conditions could drive OPEC membership, as, for instance, countries with institutions that support strong antitrust laws will not be in the cartel. Including the dummy also helps us assess whether the results in the first column are simply identifying differences between the large OPEC countries and the rest of the world or, alternatively, whether polity scores have an effect on production volatility even within OPEC and non-OPEC countries. ${ }^{17}$

In principle, it is not clear what the sign of the OPEC dummy would be, as OPEC membership could provide production discipline that reduces volatility. On the other hand, OPEC countries may adjust production to achieve price or profit goals in ways that could contribute to increased production volatility. In general, OPEC membership seems to be associated with high volatility, although the coefficient on the dummy is only significant in one specification. The coefficients on the political conditions variables are generally attenuated, suggesting that our results reflect, in part, the fact that countries with poor political conditions are in OPEC, but the coefficients on the political conditions variables are still negative, and significantly so in the case of polity, even with the OPEC dummy. ${ }^{18}$

We also included an indicator variable for countries in which there were overt nationalization acts in the oil sector. Specifically, Guriev, Kolotilin and Solin (2009) compiled a list of countries where there were, "forced divestments of foreign property," [p. 12]. Their paper investigates determinants of these nationalization acts, including political institutions. Our results suggest that countries that have had overt nationalizations have more volatile oil production, although the coefficients on the nationalization variable are never statistically significant. The coefficient estimates on the political conditions variables are all smaller in absolute value, but, at least in the case of polity, still statistically significant. This suggests that nationalizations do

\footnotetext{
${ }^{17}$ We have also estimated specifications that allow for a quadratic relationship between polity and volatility and found little evidence of important nonlinearities.

${ }^{18}$ As the results with the OPEC dummy will be identified by both variation within OPEC and variation within nonmembers, the coefficient on polity could pick up stronger cartel compliance among low polity countries. This is not the only driver of the results, though, as we have estimated specifications using only non-members and find a strong negative relationship between political conditions and volatility.
} 
impact volatility, but that political conditions appear to work through additional channels as well. ${ }^{19}$

The fourth column includes a country's average GDP per capita between 1965 and 2007. As we have discussed, previous work has found a strong, causal relationship between political conditions and economic development levels, as measured by GDP per capita, among other things. This appears true for the oil-producing countries in our data. For instance, the raw correlation between the political conditions variables and GDP per capita is strongly positive: 0.47 for polity, 0.59 for Freedom House Civil Liberties, 0.65 for Freedom House Political Rights and 0.76 for ICRG Composite Index. In the specifications in Panels B-D (which measure political conditions using Freedom House Political Rights, Freedom House Civil Liberties and the ICRG Composite Index), the coefficients on the political conditions variable are slightly larger in absolute value and remain statistically significantly negative. Contrary to expectations, the coefficient on GDP per capita is positive, though quite imprecisely estimated.

The results for the polity variable, on the other hand, accord with expectations. The coefficient on GDP is negative, though imprecisely estimated, and the coefficient on polity falls slightly in absolute value. This result suggests that, at least for polity, some of the same factors that hinder economic development contribute to higher oil market volatility. Taken together, the result in Panels A-D indicate that political conditions affect production volatility after controlling for the country's development level (as measured by per capita GDP). This buttresses the conclusion that political conditions can have real effects on production decisions in a particular market.

Finally, we include a variable to measure countries' legal environments. These specifications are not directly analogous to the others in Table 5 , as political conditions and legal environments are generally believed to arise independently. Previous work has evaluated "property rights institutions", which protect citizens from governments (and are generally measured by our political conditions variables), and contracting institutions, which facilitate commercial transactions between citizens, as competing explanations for different economic

\footnotetext{
${ }^{19}$ In unreported specifications, we also included a variable to measure the presence of a national oil company (NOC). An NOC may produce oil with more year-to-year volatility because it is constrained to pursue nonmarket objectives (Jaffee 2007). The coefficient on this variable was very imprecisely estimated in all specifications, although this is not altogether surprising since over our time period, all but four of the countries in our sample (Australia, Denmark, United Kingdom, and United States) had NOCs. This result is consistent with the idea that NOCs behave very differently depending on the political institutions within which they are operating.
} 
development levels. Measures of contracting institutions include variables such as the number of legal procedures required to settle the collection on an overdue payment. ${ }^{20}$ La Porta, Lopez-deSilanes, Shleifer and Vishny (1998) show that countries in which the legal system derives from the French (civil-law) tradition have weaker contracting institutions (e.g., higher number of procedures) than countries with legal systems derived from the English (common law) tradition. Acemoglu and Johnson (2005) show that contracting institutions matter little for macroeconomic growth once differences in political institutions are accounted for. We find a similar result for oil production volatility. ${ }^{21}$

\section{E. Specifications Using Within-Country Variation}

The regressions reported above use average political conditions measures over the sample, so the coefficients are identified by cross-country differences in political conditions. Our instruments pick up only those components of political conditions which were pre-determined before oil was a major factor in a country's economy, but our exclusion restriction will be violated if there is an omitted variable correlated both with poor political conditions and volatile production. For instance, if there is something about dominant religious institutions in a country that leads both to strong, unchecked executives and to volatility in production, our results cannot be interpreted causally. In this section, we focus on variation in the political measure as the source of instability in oil production.

\section{Regression-Based Analysis}

We estimated several specifications similar to those reported in Tables 2 through 5 using the variance in polity over our time period as the explanatory variable of interest. The coefficients, except for the univariate OLS specification, are all positive. All coefficients are statistically indistinguishable from zero. Positive coefficients, suggesting countries with more volatile political conditions have more volatile production, are generally consistent with the conclusions suggested by our previous results.

An alternative specification replaces the polity measure with the change in polity defined as the difference between the average value across the last third of a country's observations and the average of the first third of observations. The production volatility measures are also redefined as the difference between the volatility for the last third of a country's observations and

\footnotetext{
${ }^{20}$ Our variable "World Bank Procedure Count" is from World Bank (2004).

${ }^{21}$ We have also estimated 2SLS specifications, using pre-oil commercialization political conditions and legal origins as instruments, and the results are very similar to those reported.
} 
the first third of observations. The results are small and indistinguishable from zero. There appears to be too little variation in polity scores within countries over time to identify the role of changes in political conditions on oil production volatility.

\section{Analysis of Specific Cuts}

To verify that the cross-sectional results are not spurious, we took advantage of our small sample size and scrutinized 142 individual country-year observations that represented large reductions in oil production. These large reductions account for much of the variance we seek to understand. The variance (unweighted) of the percent change in production across country years is 44 with all observations. It falls by a factor of four, to 11 when we exclude the 142 country year observations that we analyze as well as the following year, as that year often reflects a mean-reverting increase.

Specifically, we started with the set of country-year observations where daily average oil production dropped by more than 100,000 barrels from the previous year. The smallest cut reflected slightly less than a one percent reduction. The list also reflects the top 16 largest percent reductions in our data set. The largest percent reduction that we did not consider (because it reflected a cut of less than 100,000 barrels per day) was in Egypt in 1972 and reflected a 28 percent reduction.

For each country-year observation, we searched the business press for explanations and descriptions of oil production in the country around that time period. We classified each cut as belonging to one of the eight categories listed in Table 6, and described more fully in the appendix.

Each country-year observation is reported in the Appendix Table along with its explanation category. We also verified the categories against several historical descriptions, including Hamilton (forthcoming), Smith (2009), Adelman (2003) and Yergin (1991).

We interpret the first four categories in Table 6 (natural disasters, technical failures, high extraction costs and mature fields) as more likely driven by market or exogenous forces and less likely reflective of political institutions. This distinction is not complete, as it is conceivable that, for instance, a natural disaster could lead to a greater production loss in a country with poor institutions if those institutions inhibited infrastructure investment. Our reading of the individual case histories suggests this is not the case, however. For instance, natural disasters have led to 
production reductions in both the U.S. (Hurricane Katrina) and Ecuador (6.9 magnitude earthquake in March 1987), though their development levels and political conditions differ.

The share of reductions driven by market or exogenous forces is much higher in countries with high polity ratings. Of the 75 observations from countries with polity ratings above 10 , almost half of the reductions were attributable to market or exogenous factors, while for countries with low polity ratings, the share is less than six percent. The difference remains pronounced even if we exclude all OPEC-related reductions (the last category): market and exogenous factors account for 60 percent of the observations in high polity countries and 15 percent of the observations in low polity countries. This analysis supports the interpretation from the previous sections that poor political institutions lead to volatile oil production.

\section{F. Political Conditions and Other Oil Production Outcomes}

Overall, our results suggest a robust causal relationship between political conditions and oil production volatility. To further explore the role of political institutions, Table 7 reports results from a specification where we examined the volatility in the number of wells in a country. ${ }^{22}$ The coefficients on polity suggest that the number of wells is also more volatile in countries with poor political conditions, consistent with the hypothesis that poor political conditions impact infrastructure investment and supply decisions. Put differently, this helps confirm that the results in Tables 2 through 5 do not reflect a spurious correlation between physical or other determinants of oil production and political institutions, but instead can be interpreted causally. The 2SLS results are nearly twice the magnitude of the OLS estimates, consistent with the presence of measurement error in the polity measure, and the results are statistically significant at the one percent level. ${ }^{23}$

The results in Table 8 speak to whether political conditions affect not just the volatility of oil production but also the absolute level. We consider the mean of production as a share of total reserves by country, under the theory that reserves are exogenous to political conditions and mainly reflect a country's natural oil endowment. The coefficient on polity is positive, suggesting that countries with good political conditions are extracting a greater share of their total reserves over the time period we examine. This could reflect several factors. For instance, it could reflect profit-maximizing withholding by monopoly state-owned oil companies in low

\footnotetext{
${ }^{22}$ We obtained data on producing wells from PennEnergy's Oil \& Gas Journal Energy Database. Data do not reflect shut in, injection, or service wells.

${ }^{23}$ Specifications including the OPEC dummy are very similar to those reported in Table 7.
} 
polity countries. Smith (2009), for instance, notes that OPEC's main success as a cartel has been in avoiding new production capacity, such that installed production facilities extract just 1.5 percent of proved reserves per year in OPEC countries versus 5.6 percent of proved reserves elsewhere. OPEC is not the entire explanation for the results in Table 8, though, as the result is robust to the inclusion of the OPEC dummy variable. The results are also robust to instrumenting for political conditions. While in no way dispositive, the result is consistent with the hypothesis that poor political conditions impede production.

\section{Implications}

Having documented the importance of a country's political conditions to its oil production, we explore how changes in average political conditions of oil producing countries affect price volatility in world oil markets. This allows us to explore whether the results we find at the micro level aggregate up to the macro level. It also allows us to analyze the impacts on volatility of changes in political conditions within countries versus changes across countries in world production shares.

To conduct this analysis we construct several indexes of the political conditions of oilproducing countries over the past several decades. In all cases we construct a political conditions measure according to the following formula (where $I_{i t}$ represents one of the political conditions measures described in the previous section for country $i$ in year $t$ and $\Pi_{t}$ is a global index based on the underlying measure):

$$
\Pi_{t}=\sum_{i} \omega_{i t} I_{i t}
$$

$\omega_{i t}$ is the share of country i's oil production in world production for year $t$. We normalize all of the indexes by dividing by the value in the first year that the index is available. The oil conditions index, $\Pi_{t}$, is a convenient measure of the average political conditions in oilproducing countries weighted by production.

Figure 2 plots the various indexes over time. The polity index begins in 1965, when the oil data are first available, while the Freedom House and ICRG indexes are constrained by data on the political conditions. Consider first the polity measure in the upper left corner of the figure. The index is initially deteriorating, falling from its 1965 value by 30 percent before bottoming out in the late 1970s. It then rises, peaking in the early 2000s about 10 percent higher than its 1965 level before beginning to deteriorate again. A similar picture emerges from the Freedom 
House indexes (note that these indexes starts seven years later). Both ICRG indexes rise through the 1980s and 1990s and then show signs of leveling off or even declining in early 2000.

\section{A. Changes in Production Shares versus Changes in Internal Conditions}

What explains the changes in the various indexes? Log differentiation of equation (5) yields:

$$
\hat{\Pi}_{t}=\sum_{i} \frac{\omega_{i t} I_{i t}}{\sum_{k} \omega_{k t} I_{k t}}\left(\hat{\omega}_{i t}+\hat{I}_{i t}\right) \equiv \sum_{i} \phi_{i t}\left(\hat{\omega}_{i t}+\hat{I}_{i t}\right)
$$

where a hat indicates a percentage change (e.g., $\left.\hat{S}_{i t}=\frac{d S_{i t}}{S_{i t}}\right)$. Changes in the oil index can be decomposed into changes in underlying country conditions and changes in countries' shares of world oil production following the work of Boyd and Roop (2004) and Metcalf (2008). Using a Fisher perfect decomposition, we decompose the oil index $\left(\Pi_{t}\right)$ into an internal-conditions index $\left(\widetilde{\Pi}_{t}^{\text {Pol }}\right)$ and production-share index $\left(\widetilde{\Pi}_{t}^{\text {Prod }}\right)$. The internal-conditions index, $\widetilde{\Pi}_{t}^{\text {Pol }}$, measures the change in the oil index holding the world oil production shares constant. ${ }^{24}$ It thus isolates the importance of political changes in oil producing countries. The oil production share index, $\widetilde{\Pi}_{t}^{\text {Prod }}$, on the other hand, measures the change in the political conditions index holding countryspecific political conditions constant. This index isolates the changes in world production and their contribution to the overall index. These indexes (known as Fisher Ideal Indexes) have the desirable property of perfect decomposition. This means that the oil index can be decomposed into these two indexes with no unexplained residual:

$$
\Pi_{t}=\widetilde{\Pi}_{t}^{\text {Pol }} \widetilde{\Pi}_{t}^{\text {Prod }}
$$

Figure 3 reproduces the three indexes available over the longest time periods (in blue) and plots each against its two components. Consider the upper left graph on Figure 3 where oil conditions are measured using the polity index. The upper gray line with squares is the internal conditions index, $\widetilde{\Pi}_{t}^{\text {Pol }}$, while the other gray line, which is below the overall index in the later years, is the production share index, $\widetilde{\Pi}_{t}^{\text {Prod }}$. Between 1965 and 1987 changes in the production share index drive changes in the overall index. In the first decade oil is increasingly produced by countries with poor political conditions measures. This partly reflects the growing share of

24 We describe the construction of the Fisher indexes in the appendix. 
OPEC and the USSR (share of world oil production rising from 61 percent in 1965 to 69 percent in 1976) and the declining share of the United States (26 percent to 14 percent over the same period). Over the next decade OPEC's share of world oil production dropped from 51 percent in 1976 to 28 percent in 1985. This followed the expansion in non-OPEC oil production following the two oil shocks of the 1970s, in particular the development of North Sea oil (rising to a world share of 6 percent by 1985) and a rebound in the US share of world oil production.

For the next twenty years changes in the production shares of world oil played little role in the steady rise in the overall index. Rather a transformation of the world political order occurred. Beginning in the mid-1980s, Gorbachev introduced democratization efforts leading up to the dissolution of the Soviet Union in 1991. Also, Mexico's polity score increased in 1988, when it held its first election with a serious opposition candidate in many years.

The decline in the oil index that began in 2003 can be explained roughly equally by declines in the internal conditions index and the oil production index. In sum, the oil index constructed from the polity measure first declines and then rises to a peak in the early 2000's before starting to decline again. Changes in the index are driven over the first half of the data by changes in the oil production share index. The internal conditions index drives changes for most of the second half of the sample.

A similar story holds for the Freedom House political rights index. Changes in both the internal conditions and the production share indexes appear to contribute to changes in the overall index prior to the mid-1980s. After that year the influence of the internal conditions index dominates until the early 2000's. Similarly the Freedom House civil liberties index shows a mixture of influences. The internal conditions index appears to dominate from roughly 1985 to the early 2000's and the production share index dominates in the last several years.

In sum, the data suggest that there has been considerable variation over the past forty years in the political structure of oil producing countries. That change has been driven at times by changes in the political structure within oil producing countries and at other times by changes in production shares across countries.

Note that these indexes will not fully describe the expected volatility in the world oil market as they do not capture the correlation in supply reductions across countries. For example, if supply reductions in countries with sound political institutions are more likely to be correlated with reductions in other countries, than, even if the analysis in section III suggests that the 
countries have less volatile production, the volatility could be nonetheless more likely to lead to large price increase. In fact, the opposite is true. Supply reductions in countries with poor political conditions are more likely to occur in years when other countries are also reducing productions. For example, considering the 142 major cuts analyzed in Section III E2, in years in which high polity countries experienced one of the reductions, total production across all other countries increased by 880,000 barrels per day, in years in which low polity countries experienced one of the reductions, total production across all other countries increased by only 130,000 . The difference is statistically significant at the five percent level. Note that the difference between high and low polity countries does not appear to be driven entirely by OPECrelated cuts, as the difference persists even when we look at cuts excluding those in the last category of Table 6 . This suggests that increased world output from low polity countries should have a greater impact on world oil prices.

\section{B. Political Conditions and Macroeconomic Indicators}

A natural question to ask is whether the changes over time in the weighted-average political condition have in fact impacted world oil markets. For instance, we might suspect that as production moves away from countries with poor political conditions, which we demonstrated in the previous section had more volatile production, volatility in prices would decline. Table 9 reports results from simple time series regressions which use two of the three indexes depicted in the upper left panel of Figure 3, decomposing the polity measure, to predict oil price volatility. ${ }^{25}$ We measure oil price volatility in two ways. In the first and third columns, we measure the within-year variance in the spot price (using data from the Global Financial Database, Commodity Price series). As spot prices are only really meaningful beginning in the early 1980s, we use data from the last 25 years of our sample (1983-2007). In the second and fourth columns, we measure price volatility using the absolute value of the difference between the oil forward contract closing price traded three-months prior to delivery minus the delivery date's closing spot price. (The last daily trade in a month is used as the monthly observation of spot price and as the contract delivery date.) This measure will capture unexpected changes in the market over the short run, which could be driven by supply-side disruptions caused by the political conditions in the oil-producing countries.

\footnotetext{
${ }^{25}$ Although the indexes are not additive, the results for the third index were similar to the linear combination of the other two indexes, so we report results using only two of the three indexes.
} 
The top panel of Table 9 uses the overall political conditions index as the independent variable, and the bottom panel uses the production share index as the independent variable. The results at the top of the table suggest that there is little, or if anything positive, correlation between the overall polity index and price volatility, which is inconsistent with our hypothesis. The results at the bottom without a trend suggest a distinct negative effect of increasing the production share index on price volatility. The coefficient estimates fall and become statistically insignificant when we add a linear trend, although with only 25 observations over time, it may be too difficult to detect a relationship based on deviations around a trend. Overall, the results may suggest that it takes time before short-run changes in political conditions impact oil production in a country, but that shifts in production to countries with long histories of good governance will lead to lower price volatility.

\section{Interpreting Our Results}

We have argued that a link exists between political conditions in a country and the stability of the country's oil production. Empirical evidence suggests that more democratic countries have more stable production over time. Moreover our preferred political conditions index of oil supply suggests a recent downturn in polity among oil producing nations.

One should not, however, interpret our results as suggesting a new rationale for government intervention in energy markets to promote energy security. For example, it would be incorrect to interpret our results as supporting a policy of more domestic supply to reduce oil imports. We say this first because supply shocks of the sort that we investigate in this papercountry-specific and largely idiosyncratic shocks - can in general be quickly replaced in world markets by other suppliers. Thus price shocks are for the most part short-lived. ${ }^{26}$ Second, oil is a fungible commodity and price shocks arising from a supply shortfall anywhere in the world affects all oil consumers regardless of the source of their particular oil. As noted by Deutch and Schlesinger (2006) and the National Research Council (2009), among others, a country's vulnerability to oil shocks depends on its consumption of oil relative to the size of its economy rather than its imports.

\footnotetext{
26 This is not to suggest that idiosyncratic supply shocks are entirely unimportant. They can contribute to an atmosphere of concern about supply that feeds into a precautionary demand shock as described by Kilian (2008). Also, as noted above, low polity countries are more likely to have supply reductions that are correlated with other countries reductions.
} 
The results do enhance our understanding of the relationship between political governance and energy supply and more generally of the connections between political institutions and economic performance. In that vein, our paper can be viewed as a contribution towards opening up Acemoglu, Johnson and Robinson's "black box" to see an example where governance affects the workings of a particular market, one that happens to be of particular importance to the world economy.

\section{Conclusion}

We have analyzed how political conditions in oil producing countries affect the volatility of oil production as well as other oil market outcomes. We show that there is a pronounced negative relationship between the short-run volatility in oil production in a country and its political openness, with very democratic regimes exhibiting less volatility in their oil production than more autocratic regimes. This result holds across several robustness checks including using different measures of political conditions, instrumenting for political conditions and using different measures of oil production volatility.

We next document that the average political conditions of oil producing countries has changed markedly over the past thirty-five to forty years. Using the polity composite democracy index, for example, we find that our oil index falls by 30 percent between 1965 and 1976 and then nearly doubles over the next twenty-eight years. Over the past five years it has fallen by roughly five percent. We then decompose that index into a political index that controls for the distribution of oil production across countries and a production share index that controls for the political structure of producing countries. Again using the polity measure, early changes in our oil security index are driven by the distribution of countries producing oil while latter changes are driven more by changes in political conditions within producing countries.

One should be cautious in drawing policy recommendations from this finding. It does suggest that a research agenda focusing on the role of political institutions in affecting global energy markets is a fruitful one. This paper takes a reduced form approach. Subsequent research will be important to begin to understand the mechanisms that affect supply volatility and what the implications are for policy. Also, our index measures could be used to analyze the potential risks associated with different renewable energy technologies, many of which (for instance, solar electricity and electric vehicles) rely on natural resources that are available in a limited set of countries. 


\section{References}

Acemoglu, Daron, and Simon Johnson, 2005, Unbundling institutions, Journal of Political Economy 113, 949-995.

Acemoglu, Daron, Simon Johnson, and James A. Robinson, 2001, The colonial origins of comparative development: An empirical investigation, American Economic Review 91, 1369-1401.

Acemoglu, Daron, Simon Johnson, James A. Robinson, and Yunyong Thaicharoen, 2003, Institutional causes, macroeconomic symptoms: Volatility, crises and growth, Journal of Monetary Economics 50, 49-123.

Adelman, M. A., 2002, World oil production and prices: 1947-2000, Quarterly Review of Economics and Finance, 42, 169-91.

Alexeev, Michael, and Robert Conrad, 2009, The elusive curse of oil, Review of Economics and Statistics 91, 586-598.

Andrews, Edmund L., 2009, Call to curb speculators in energy, The New York Times (New York).

Barro, Robert, 1997. Determinants of economic growth: A cross-country empirical study (MIT Press, Cambridge).

Basedau, Matthias, and Wolfram Lacher, 2006, A paradox of plenty? Rent distribution and political stability in oil states, (GIGA, Hamburg).

Bohn, Henning, and Robert T. Deacon, 2000, Ownership risk, investment, and the use of natural resources, American Economic Review 90, 526-549.

Boyd, Gale A., and Joseph M. Roop, 2004, A note on the fisher ideal index decomposition for structural change in energy intensity, Energy Journal 25, 87-101.

BP, 2009, Bp statistical review of world energy june 2009.

Chinn, Menzie D., and Hiro Ito, 2006, What matters for financial development? Capital controls, institutions, and interactions, Journal of Development Economics 81, 163-192.

Deutch, John, and James Schlesinger, 2006, National security consequences of U.S. Oil dependency (Council on Foreign Relations, Washington, DC).

Du, Julan, 2010, Institutional quality and economic crises: Legal origin theory versus colonial strategy theory, Review of Economics and Statistics 92, 173-179.

Eichengreen, Barry, Rachita Gullapalli, and Ugo Panizza, 2009, Capital account liberalization, financial development and industry growth: A synthetic view (University of California Berkeley, Berkeley).

Fisher, Irving, 1921, The best form of index number, Quarterly Publications of the American Statistical Association 17, 533-537.

Haber, Stephen, and Victor Menaldo, 2008, Do natural resources fuel authoritarianism? A reappraisal of the resource curse.

Hall, Robert E., and Charles Jones, 1999, Why do some countries produce so much more output per worker than others?, Quarterly Journal of Economics 114, 83-116.

Hamilton, James, 2009, Causes and consequences of the oil shock of 2007-2008, (Brookings Institution, Washington, DC).

Hamilton, James, forthcoming, Historical oil shocks, in Handbook of Major Events in Economic History, edited by Randall Parker and Robert Whaples, Routledge. 
Hubbert, M. King, 1956, Nuclear energy and the fossil fuels, (Shell Development Company Exploration and Research Division, Houston).

Kilian, Lutz, 2008, The economic effects of energy price shocks, Journal of Economic Literature 46, 871-909.

Kilian, Lutz, 2009, Not all oil price shocks are alike: Disentangling demand and supply shocks in the crude oil market, American Economic Review 99, 1053-1069.

Kose, M. Ayhan, Eswar Prasad, Kenneth S. Rogoff, and Shang-Jin Wei, 2006, Financial globalization: A reappraisal, (National Bureau of Economic Research, Cambridge, MA).

La Porta, Rafael, Florencio Lopez-de-Silanes, Andrei Shleifer, and Robert W. Vishny, 1998, Law and finance, Journal of Political Economy 106, 1113-1155.

Lane, Philip R., and Gian Maria Milesi-Ferretti, 2006, The external wealth of nations mark ii: Revised and extended estimates of foreign assets and liabilities, 1970-2004, (International Monetary Fund, Washington, DC).

Marshall, Monty G., and Keith Jaggers, 2009, Polity iv project, political regime characteristics and transitions, 1800-2007 dataset users' manual, (George Mason University, Arlington, VA).

Metcalf, Gilbert E., 2008, An empirical analysis of energy intensity and its determinants at the state level, The Energy Journal 29, 1-26.

Mulligan, Casey B., Ricard Gil, and Xavier Sala-i-Martin, 2004, Do democracies have different public policies than nondemocracies? Journal of Economic Perspectives 18, 51-74.

National Research Council, 2009. Hidden costs of energy: Unpriced consequences of energy production and use (National Academies Press, Washington, DC).

Perrson, Torsten, and Guido Tabellini, 2003. The economic effects of constitutions (MIT Press, Cambridge).

Rajan, Raghuram, and Luigi Zingales, 1998, Financial dependence and growth, American Economic Review 88, 559-586.

Rodrik, Dani, 1999, Democracies pay higher wages, Quarterly Journal of Economics 114, 707738.

Ross, Michael L., 2001, Does oil hinder democracy?, World Politics 53, 325-361.

Smith, Benjamin, 2004, Oil wealth and regime survival in the developing world, 1960-1999, American Journal of Political Science 48, 232-246.

Smith, James L., 2009, World oil: Market or mayhem? Journal of Economic Perspectives 23, 145-164.

Tsui, Kevin K., 2008, Resource curse? A theory of contestable political markets with endogenous entry barriers, (Department of Economics, Clemson University, Clemson, $\mathrm{SC})$.

Wacziarg, Romain, 2009, The first law of petropolitics, (UCLA, Los Angeles).

Yergin, Daniel, 1991, The prize: The epic quest for oil, money and power, New York: Free Press. 
Table 1. Summary Statistics

\begin{tabular}{|c|c|c|c|c|c|}
\hline Variable & Mean & $\begin{array}{l}\text { Standard } \\
\text { Deviation }\end{array}$ & Minimum & Maximum & $\begin{array}{c}\text { Years } \\
\text { Covered }\end{array}$ \\
\hline \multicolumn{6}{|l|}{ Oil Production Volatility Measures } \\
\hline $\operatorname{Stdev}\left[\ln Q_{t}-\ln Q_{t-1}\right]$ & 0.191 & 0.163 & 0.029 & 1.001 & $1965-2007$ \\
\hline $\operatorname{Stdev}\left[\left(\ln Q_{t}-\operatorname{lnGDP} t\right)-\left(\ln Q_{t-1}-\ln G_{t} P_{t-1}\right)\right]$ & 0.198 & 0.160 & 0.062 & 0.986 & $1965-2007$ \\
\hline $\operatorname{Stdev}\left[\ln \mathrm{Q}_{\mathrm{t}}-\ln \mathrm{Q}_{\mathrm{t}-1}\right]$ & 0.158 & 0.180 & 0.020 & 1.001 & 1980-2007 \\
\hline $\operatorname{Stdev}\left[\left(\ln \mathrm{Q}_{t}-\operatorname{lnGDP}_{t}\right)-\left(\ln _{\mathrm{t}-1}-\ln \mathrm{GDP}_{\mathrm{t}-1}\right)\right]$ & 0.169 & 0.175 & 0.051 & 0.986 & 1980-2007 \\
\hline $\begin{array}{l}\operatorname{Stdev}\left[\left(\operatorname{lnQ}_{t}-\ln \operatorname{lnDP}_{t}-\ln \text { Reserves }_{t}\right)-\right. \\
\left.\quad\left(\ln Q_{t-1}-\ln _{\text {nDP }} \text { t }_{t-1}-\operatorname{lnReserves~}_{t-1}\right)\right]\end{array}$ & 0.230 & 0.192 & 0.059 & 0.987 & 1980-2007 \\
\hline Largest one-year percentage decline & 0.212 & 0.179 & 0.000 & 0.867 & 1965-2007 \\
\hline Largest one-year percentage decline & 0.168 & 0.169 & 0.000 & 0.867 & 1980-2007 \\
\hline Volatility in Wells & 0.221 & 0.209 & 0.000 & 0.896 & 1980-2006 \\
\hline Production/Reserves & 0.061 & 0.035 & 0.007 & 0.175 & 1980-2007 \\
\hline \multicolumn{6}{|l|}{ Explanatory Variables } \\
\hline Polity & 10.0 & 7.0 & 1.0 & 21.0 & $1965-2007$ \\
\hline 1900 Polity Broad & 8.9 & 7.2 & 1 & 21 & See text \\
\hline 1900 Polity Strict & 7.4 & 6.7 & 1 & 21 & " \\
\hline Freedom House Political Rights & 3.4 & 2.1 & 1.0 & 7.0 & $1972-2007$ \\
\hline Freedom House Civil Liberties & 3.6 & 1.8 & 1.0 & 7.0 & $1972-2007$ \\
\hline ICRG Risk of Expropriation & 7.5 & 1.5 & 2.5 & 9.9 & 1982-1997 \\
\hline $\begin{array}{l}\text { ICRG composite index (aggregate of } 5 \\
\text { ICRG measures) }\end{array}$ & 31.0 & 8.1 & 14.6 & 49.4 & 1982-1997 \\
\hline Financial Openness & 1.3 & 1.0 & 0.3 & 5.8 & $1970-2007$ \\
\hline OPEC Membership & 0.2 & 0.4 & 0.0 & 1.0 & $1965-2007$ \\
\hline Act of Nationalization & 0.5 & 0.5 & 0.0 & 1.0 & $1960-2006$ \\
\hline National Oil Company & 0.9 & 0.3 & 0.0 & 1.0 & $1965-2007$ \\
\hline Average GDP per Capita & 5724 & 7683 & 328 & 30013 & 1965-2007 \\
\hline World Bank Procedure Count & 27.2 & 11.9 & 11.0 & 54.0 & 2004 \\
\hline Common Law Origins & 0.3 & 0.4 & 0.0 & 1.0 & NA \\
\hline Land Area (millions of square miles) & 2.1 & 3.5 & 0.0 & 17.1 & $1965-2007$ \\
\hline
\end{tabular}


Table 2. Volatility and Polity

\begin{tabular}{|c|c|c|c|c|}
\hline \multirow[b]{2}{*}{ Volatility Measure } & \multicolumn{2}{|c|}{ Data range: 1980-2007 } & \multicolumn{2}{|c|}{ Data range: 1965-2007 } \\
\hline & $\begin{array}{c}\text { Coefficient } \\
\text { on } \\
\text { mean(Polity) }\end{array}$ & $R^{2}$ & $\begin{array}{c}\text { Coefficient } \\
\text { on } \\
\text { mean(Polity) }\end{array}$ & $R^{2}$ \\
\hline $\operatorname{Stdev}\left[\ln Q_{t}-\ln Q_{t-1}\right]$ & $\begin{array}{l}-0.0068 * * * \\
(0.0023)\end{array}$ & 0.185 & $\begin{array}{l}-0.0060 * * \\
(0.0024)\end{array}$ & 0.175 \\
\hline $\begin{aligned} \operatorname{Stdev}[ & \left(\ln \mathrm{Q}_{\mathrm{t}}-\beta_{1} \mathrm{t}-\beta_{2} \mathrm{t}^{2}\right)- \\
& \left.\left(\ln \mathrm{Q}_{\mathrm{t}-1} \beta_{1}(\mathrm{t}-1)-\beta_{2}(\mathrm{t}-1)^{2}\right)\right]\end{aligned}$ & $\begin{array}{l}-0.0068 * * * \\
(0.0022)\end{array}$ & 0.207 & $\begin{array}{l}-0.0062 * * * \\
(0.0023)\end{array}$ & 0.212 \\
\hline $\begin{aligned} \operatorname{Stdev}[ & \left(\ln \mathrm{Q}_{\mathrm{t}}-\ln \mathrm{GDP}_{\mathrm{t}}\right)- \\
& \left.\left(\ln \mathrm{Q}_{\mathrm{t}-1}-\ln \mathrm{GDP}_{\mathrm{t}-1}\right)\right]\end{aligned}$ & $\begin{array}{l}-0.0052 * * \\
(0.0023)\end{array}$ & 0.120 & $\begin{array}{r}-0.0048 * * \\
(0.0023) \\
\end{array}$ & 0.122 \\
\hline $\begin{array}{l}\text { Stdev }\left[\left(\operatorname{lnQ}_{t}-\operatorname{lnGDP} P_{t}-\ln \text { Reserves }_{t}\right)-\right. \\
\left.\left.\quad \ln Q_{t-1}-\ln \operatorname{lnDP}_{t-1}-\ln \operatorname{Reserves}_{t-1}\right)\right]\end{array}$ & $\begin{array}{l}-0.0053 * * \\
(0.0026)\end{array}$ & 0.113 & & \\
\hline Largest one-year percentage decline & $\begin{array}{l}-0.0118 * * * \\
(0.0036)\end{array}$ & 0.249 & $\begin{array}{c}-0.0138 * * * \\
(0.0038)\end{array}$ & 0.266 \\
\hline \multicolumn{5}{|c|}{$\begin{array}{l}\text { Robust standard errors in parentheses. All specifications are weighted by a country's average production within the } \\
\text { appropriate time period. The first two columns present results where the dependent variable is estimated over the } \\
\text { range } 1981-2007 \text {, where the first year is one year after the data begins since the dependent variables are in first } \\
\text { differences. The two right-most columns present results where the dependent variable is estimated over the data } \\
\text { range } 1966-2007 . \mathrm{N}=48 \text {, rows } 1-3,5 ; \mathrm{N}=47 \text {, row } 4 \text { (data on reserves in Cameroon are not available). } \\
* \text { - p-value less than } 10 \text { percent } \\
* * \text { - p-value less than } 5 \text { percent } \\
* * * \text { - p-value less than } 1 \text { percent }\end{array}$} \\
\hline
\end{tabular}


Table 3. Volatility and Polity: Two-Stage Least Squares

\begin{tabular}{|l|c|c|}
\hline & 2SLS & 2SLS \\
\hline & 1900 Polity (Broad) & 1900 Polity (Strict) \\
\hline Polity & -0.0031 & -0.0038 \\
& $(0.0035)$ & $(0.0026)$ \\
\hline $\begin{array}{l}\text { First- } \\
\text { stage F- } \\
\text { statistic }\end{array}$ & 48.66 & 55.29 \\
\hline & & \\
\hline & OLS & OLS \\
\hline Polity & $-0.0063^{* *}$ & $-0.0045^{* *}$ \\
& $(0.0025)$ & $(0.0019)$ \\
\hline $\mathrm{R}^{2}$ & 0.186 & .1633 \\
\hline Obs & 46 & 33 \\
\hline
\end{tabular}

Robust standard errors in parentheses. All specifications are weighted by a country's average production between 1965-2007.

* - p-value less than 10 percent

** - p-value less than 5 percent

*** - p-value less than 1 percent 
Table 4. Oil Production Volatility Regressions: Alternative Political Measures

\begin{tabular}{|l|c|c|}
\hline & OLS & 2SLS \\
\hline $\begin{array}{l}\text { Freedom House } \\
\text { Political Rights }\end{array}$ & $\begin{array}{c}-0.0169^{* *} \\
(0.0081)\end{array}$ & $\begin{array}{c}-0.0150 \\
(0.0091)\end{array}$ \\
\hline $\mathrm{R}^{2}$ & 0.114 & \\
\hline $\begin{array}{l}\text { First-stage F- } \\
\text { statistic }\end{array}$ & & 63.06 \\
\hline $\begin{array}{l}\text { Freedom House } \\
\text { Civil Liberties }\end{array}$ & $\begin{array}{c}-0.0188^{* *} \\
(0.0082)\end{array}$ & $\begin{array}{c}-0.0154^{*} \\
(0.0092)\end{array}$ \\
\hline $\mathrm{R}^{2}$ & 0.124 & \\
\hline $\begin{array}{l}\text { First-stage } \\
\text { F-statistic }\end{array}$ & & 68.14 \\
\hline $\begin{array}{l}\text { Risk of } \\
\text { Expropriation }\end{array}$ & $-0.0349^{*}$ & $-0.0407^{* *}$ \\
& $(0.0175)$ & $(0.0186)$ \\
\hline $\mathrm{R}^{2}$ & 0.175 & \\
\hline $\begin{array}{l}\text { First-stage F- } \\
\text { statistic }\end{array}$ & & 4.89 \\
\hline $\begin{array}{l}\text { ICRG composite } \\
\text { index }\end{array}$ & $-0.0050^{* *}$ & $-0.0046^{* *}$ \\
\hline $\mathrm{R}^{2}$ & $(0.0024)$ & $(0.0022)$ \\
\hline $\begin{array}{l}\text { First-stage } \\
\text { F-statistic }\end{array}$ & 0.120 & 19.81 \\
\hline
\end{tabular}

$\mathrm{N}=48$ for OLS specifications (46 for last two measures). $\mathrm{N}=46$ for 2SLS specifications (44 for last two measures). Robust standard errors in parentheses. The specifications for the first two alternative measures are weighted by a country's average production between 1972 and 2007 . The specifications for the last two alternative measures are weighted by a country's average production between 1982 and 1997. 2SLS results use 1900 Polity (Broad) as the instrument. 
Table 5. Volatility and Political Conditions with Additional Covariates

\begin{tabular}{|l|l|l|l|l|l|l|}
\hline PANEL A & $\begin{array}{l}\text { Bench- } \\
\text { mark }\end{array}$ & $\begin{array}{l}\text { Financial } \\
\text { Openness }\end{array}$ & OPEC & $\begin{array}{l}\text { Act of } \\
\text { National- } \\
\text { ization }\end{array}$ & $\begin{array}{l}\text { GDP per } \\
\text { capita }\end{array}$ & $\begin{array}{l}\text { WB } \\
\text { Procedure } \\
\text { Count }\end{array}$ \\
\hline Polity & $-0.0047^{* *}$ & $-0.0040^{* * *}$ & $-0.0048^{* *}$ & $-0.0038^{*}$ & -0.0041 & $-0.0041^{*}$ \\
& $(0.0020)$ & $(0.0015)$ & $(0.0019)$ & $(0.0022)$ & $(0.0028)$ & $(0.0021)$ \\
\hline Covariate & & 0.0308 & -0.0047 & 0.0215 & -0.0010 & -0.0021 \\
& & $(0.0187)$ & $(0.0413)$ & $(0.0270)$ & $(0.0022)$ & $(0.0015)$ \\
\hline
\end{tabular}

\begin{tabular}{|l|l|l|l|l|l|l|}
\hline PANEL B & $\begin{array}{l}\text { Bench- } \\
\text { mark }\end{array}$ & $\begin{array}{l}\text { Financial } \\
\text { Openness }\end{array}$ & OPEC & $\begin{array}{l}\text { Act of } \\
\text { National- } \\
\text { ization }\end{array}$ & $\begin{array}{l}\text { GDP per } \\
\text { capita }\end{array}$ & $\begin{array}{l}\text { WB } \\
\text { Procedure } \\
\text { Count }\end{array}$ \\
\hline $\begin{array}{l}\text { FH } \\
\text { Political } \\
\text { Rights }\end{array}$ & $\begin{array}{l}-0.0149 * * \\
(0.0062)\end{array}$ & $\begin{array}{l}-0.0125^{* * *} \\
(0.0037)\end{array}$ & $\begin{array}{l}-0.0109 \\
(0.0069)\end{array}$ & $\begin{array}{l}-0.0102 \\
(0.0072)\end{array}$ & $\begin{array}{l}-0.0157^{*} \\
(0.0082)\end{array}$ & $\begin{array}{l}-0.0119^{* *} \\
(0.0057)\end{array}$ \\
\hline Covariate & & 0.0370 & 0.0512 & 0.0337 & 0.0004 & -0.0025 \\
& $(0.0225)$ & $(0.0448)$ & $(0.0318)$ & $(0.0022)$ & $(0.0015)$ \\
\hline
\end{tabular}

\begin{tabular}{|c|c|c|c|c|c|c|}
\hline PANEL C & $\begin{array}{l}\text { Bench- } \\
\text { mark }\end{array}$ & $\begin{array}{l}\text { Financial } \\
\text { Openness }\end{array}$ & OPEC & $\begin{array}{l}\text { Act of } \\
\text { National- } \\
\text { ization }\end{array}$ & $\begin{array}{l}\text { GDP per } \\
\text { capita }\end{array}$ & $\begin{array}{l}\text { WB } \\
\text { Procedure } \\
\text { Count }\end{array}$ \\
\hline $\begin{array}{l}\text { FH Civil } \\
\text { Liberties }\end{array}$ & $\begin{array}{l}-0.0165 * * \\
(0.0063)\end{array}$ & $\begin{array}{l}-0.0144 * * * \\
(0.0035)\end{array}$ & $\begin{array}{l}-0.0120 \\
(0.0075)\end{array}$ & $\begin{array}{l}-0.0120 \\
(0.0082)\end{array}$ & $\begin{array}{l}-0.0191 * * \\
(0.0092)\end{array}$ & $\begin{array}{l}-0.0136 * * \\
(0.0058)\end{array}$ \\
\hline Covariate & & $\begin{array}{l}0.0383 * \\
(0.0222)\end{array}$ & $\begin{array}{l}0.0465 \\
(0.0473)\end{array}$ & $\begin{array}{l}0.0292 \\
(0.0356)\end{array}$ & $\begin{array}{l}0.0010 \\
(0.0023)\end{array}$ & $\begin{array}{l}-0.0026^{*} \\
(0.0015)\end{array}$ \\
\hline
\end{tabular}

\begin{tabular}{|l|l|l|l|l|l|l|}
\hline PANEL D & $\begin{array}{l}\text { Bench- } \\
\text { mark }\end{array}$ & $\begin{array}{l}\text { Financial } \\
\text { Openness }\end{array}$ & OPEC & $\begin{array}{l}\text { Act of } \\
\text { National- } \\
\text { ization }\end{array}$ & $\begin{array}{l}\text { GDP per } \\
\text { capita }\end{array}$ & $\begin{array}{l}\text { WB } \\
\text { Procedure } \\
\text { Count }\end{array}$ \\
\hline $\begin{array}{l}\text { ICRG } \\
\text { composite } \\
\text { index }\end{array}$ & $\begin{array}{l}-0.0040^{*} \\
(0.0022)\end{array}$ & $\begin{array}{l}-0.0022^{* *} \\
(0.0011)\end{array}$ & $\begin{array}{l}-0.0021 \\
(0.0020)\end{array}$ & $\begin{array}{l}-0.0015 \\
(0.0040)\end{array}$ & $\begin{array}{l}-0.0103^{*} \\
(0.0061)\end{array}$ & $\begin{array}{l}-0.0039^{* *} \\
(0.0016)\end{array}$ \\
\hline Covariate & & $\begin{array}{l}0.0411 \\
(0.0322)\end{array}$ & $\begin{array}{l}0.1069 * \\
(0.0548)\end{array}$ & $\begin{array}{l}0.0586 \\
(0.0580)\end{array}$ & $\begin{array}{l}0.0079 \\
(0.0060)\end{array}$ & $\begin{array}{l}-0.0046^{* *} \\
(0.0021)\end{array}$ \\
\hline
\end{tabular}

Land area is included in all specifications, but coefficient estimates are not shown. Standard errors are in parentheses. All regressions are cross-sectional OLS with one observation per country. Each column in each panel reports results from a separate regression. $\mathrm{N}=48$ for all cells in Panels A-C (except 47 for the Financial Openness specifications). $\mathrm{N}=45$ for Panel D (except 44 for the Financial Openness specification). 
Table 6. Large Production Reductions by Category

\begin{tabular}{|c|c|c|c|}
\hline Reduction Explanation & Share - Overall & $\begin{array}{c}\text { Share- High Polity } \\
\text { Countries }\end{array}$ & \begin{tabular}{|c|}
$\begin{array}{c}\text { Share- Low Polity } \\
\text { Countries }\end{array}$ \\
\end{tabular} \\
\hline Natural Disaster & $1 \%$ & \multirow{4}{*}{$47 \%$} & \multirow[t]{4}{*}{ 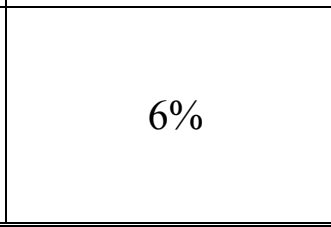 } \\
\hline Technical Failure & $4 \%$ & & \\
\hline High Extraction Costs & $3 \%$ & & \\
\hline \begin{tabular}{|l|} 
Mature Fields \\
\end{tabular} & $19 \%$ & & \\
\hline Nationalization & $10 \%$ & \multirow{4}{*}{$53 \%$} & \multirow{4}{*}{$94 \%$} \\
\hline Domestic Conflict & $13 \%$ & & \\
\hline $\begin{array}{l}\text { International Conflict (War, } \\
\text { Embargo, Blockade, etc.) }\end{array}$ & $10 \%$ & & \\
\hline Market Power & $40 \%$ & & \\
\hline $\mathrm{N}$ & 142 & 75 & 67 \\
\hline
\end{tabular}

Source: Authors' analysis. See Appendix for details. 
Table 7. Volatility in Oil Producing Wells and Polity

\begin{tabular}{|c|c|c|c|c|}
\hline & \multicolumn{2}{|c|}{ OLS } & \multicolumn{2}{|c|}{ 2SLS } \\
\hline Polity & $\begin{array}{l}-0.0116^{*} \\
(0.0064) \\
\end{array}$ & $\begin{array}{l}-0.0116^{*} \\
(0.0066) \\
\end{array}$ & $\begin{array}{l}-0.0204 * * * \\
(0.0074)\end{array}$ & $\begin{array}{l}-0.0206 * * * \\
(0.0076)\end{array}$ \\
\hline Land Area & & $\begin{array}{l}-0.0010 \\
(0.0102)\end{array}$ & & $\begin{array}{l}-0.0018 \\
(0.0075)\end{array}$ \\
\hline $\mathrm{R}^{2}$ & 0.251 & 0.252 & & \\
\hline $\begin{array}{l}\text { First Stage F- } \\
\text { Statistic }\end{array}$ & & & 21.09 & 16.40 \\
\hline \multicolumn{5}{|c|}{$\begin{array}{l}\text { Robust standard errors in parentheses. All specifications are weighted by a country's } \\
\text { average wells between } 1980 \text { and 2006. Producing wells data from the Oil \& Gas Journal } \\
\text { Energy Database. Wells totals do not include shut in, injection, or service wells. There are } \\
48 \text { observations in the OLS regressions and } 46 \text { in the 2SLS regressions. 2SLS results use } \\
1900 \text { Polity (Broad) as the instrument. }\end{array}$} \\
\hline
\end{tabular}

Table 8. Oil Production as a Fraction of Reserves and Polity

\begin{tabular}{|c|c|c|c|c|}
\hline & \multicolumn{2}{|c|}{ OLS } & \multicolumn{2}{c|}{ 2SLS } \\
\hline Polity & $\begin{array}{c}0.0035^{* * *} \\
(0.0008)\end{array}$ & $\begin{array}{c}0.0020^{* *} \\
(0.0007)\end{array}$ & $\begin{array}{c}0.0042^{* * *} \\
(0.0008)\end{array}$ & $\begin{array}{c}0.0030 * * * \\
(0.0009)\end{array}$ \\
\hline Land Area & & $\begin{array}{c}-0.0004 \\
(0.0010)\end{array}$ & & $\begin{array}{c}-0.0003 \\
(0.0009)\end{array}$ \\
\hline OPEC & & $\begin{array}{c}-0.0424 * * * \\
(0.0125)\end{array}$ & & $\begin{array}{c}-0.0378 * * * \\
(0.0146)\end{array}$ \\
\hline $\mathrm{R}^{2}$ & 0.457 & 0.622 & 0.463 & 0.653 \\
\hline First Stage F- \\
Statistic
\end{tabular}

Robust standard errors in parentheses. All specifications are weighted by a country's average production between 1980 and 2007. OLS regressions have 47 observations and the 2SLS 46. 2SLS results use 1900 Polity (Broad) as the instrument.

* - p-value less than 10 percent

** - p-value less than 5 percent

*** - p-value less than 1 percent 
Table 9. Oil Price Volatility and Political Conditions

\begin{tabular}{|c|c|c|c|c|}
\hline & $\begin{array}{l}\text { Spot Price } \\
\text { Volatility }\end{array}$ & $\begin{array}{l}\text { Forward } \\
\text { minus } \\
\text { Spot Price }\end{array}$ & $\begin{array}{l}\text { Spot Price } \\
\text { Volatility }\end{array}$ & $\begin{array}{l}\text { Forward } \\
\text { minus } \\
\text { Spot Price }\end{array}$ \\
\hline Polity Index & $\begin{array}{l}0.1526 \\
(0.0921)\end{array}$ & $\begin{array}{l}9.147 * * * \\
(2.505)\end{array}$ & $\begin{array}{l}0.0027 \\
(0.1456)\end{array}$ & $\begin{array}{l}-11.33 \\
(7.67)\end{array}$ \\
\hline Trend & & & $\begin{array}{l}0.0021 \\
(0.0019)\end{array}$ & $\begin{array}{l}0.2929 * * \\
(0.1083)\end{array}$ \\
\hline $\mathrm{R}^{2}$ & 0.129 & 0.153 & 0.155 & 0.653 \\
\hline $\begin{array}{l}\text { Polity Production } \\
\text { Share Index }\end{array}$ & $\begin{array}{l}-0.5395^{*} \\
(0.2728)\end{array}$ & $\begin{array}{l}-45.65 * * \\
(17.91)\end{array}$ & $\begin{array}{l}-0.2347 \\
(0.6391)\end{array}$ & $\begin{array}{l}-14.77 \\
(16.99)\end{array}$ \\
\hline Trend & & & $\begin{array}{l}0.0015 \\
(0.0025)\end{array}$ & $\begin{array}{l}0.1332 \\
(0.0343)\end{array}$ \\
\hline $\mathrm{R}^{2}$ & 0.056 & 0.405 & 0.161 & 0.600 \\
\hline \multicolumn{5}{|c|}{$\begin{array}{l}\text { Regressions are run using data from } 1983 \text { through } 2007 \text { ( } 25 \text { observations). Estimated } \\
\text { using a Prais-Winsten transformation to adjust for the presence of serial correlation. } \\
* \text { - p-value less than } 10 \text { percent } \\
* * \text { - p-value less than } 5 \text { percent } \\
* * * \text { - p-value less than } 1 \text { percent }\end{array}$} \\
\hline
\end{tabular}


Figure 1

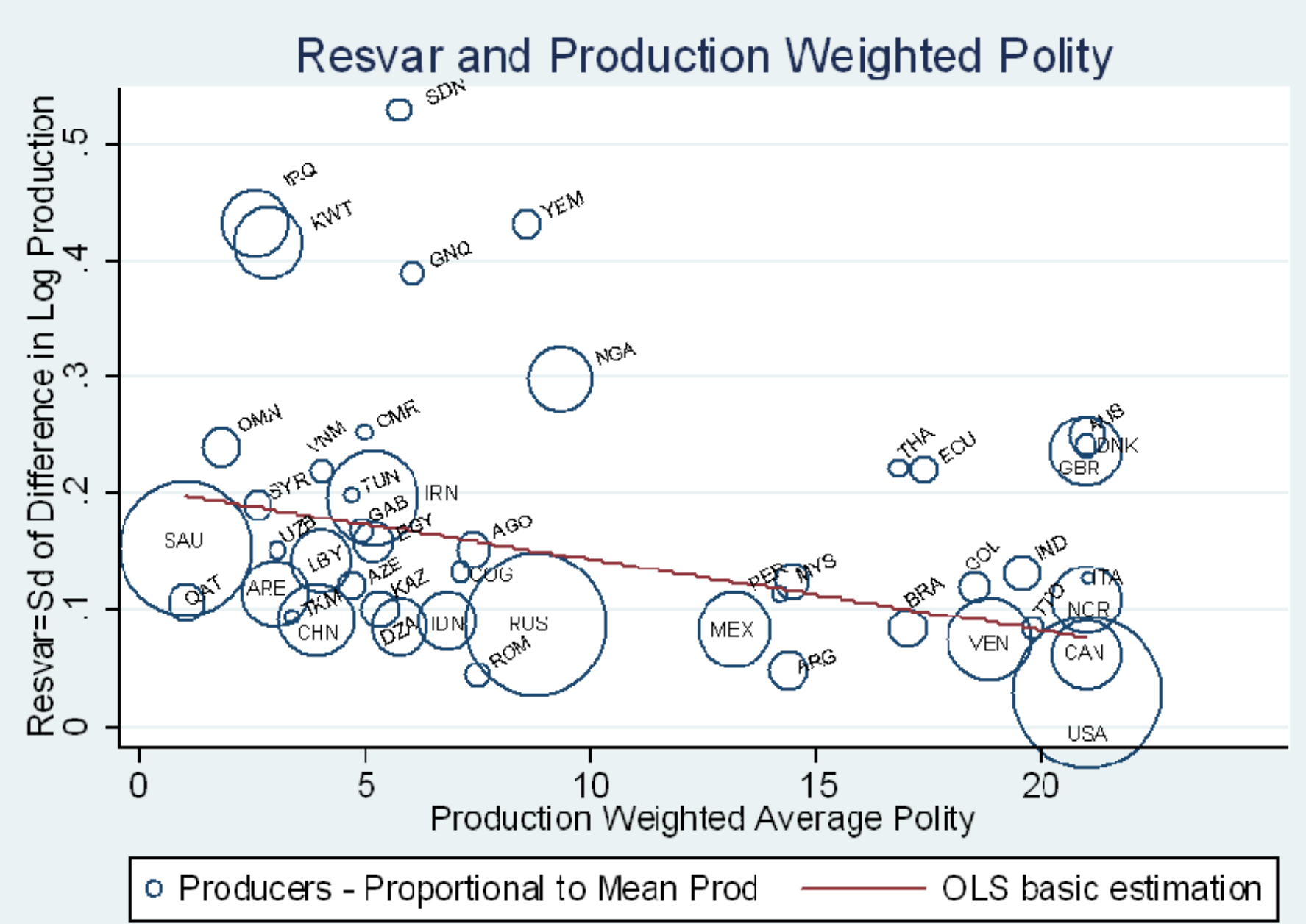


Figure 2. Political Conditions Indexes
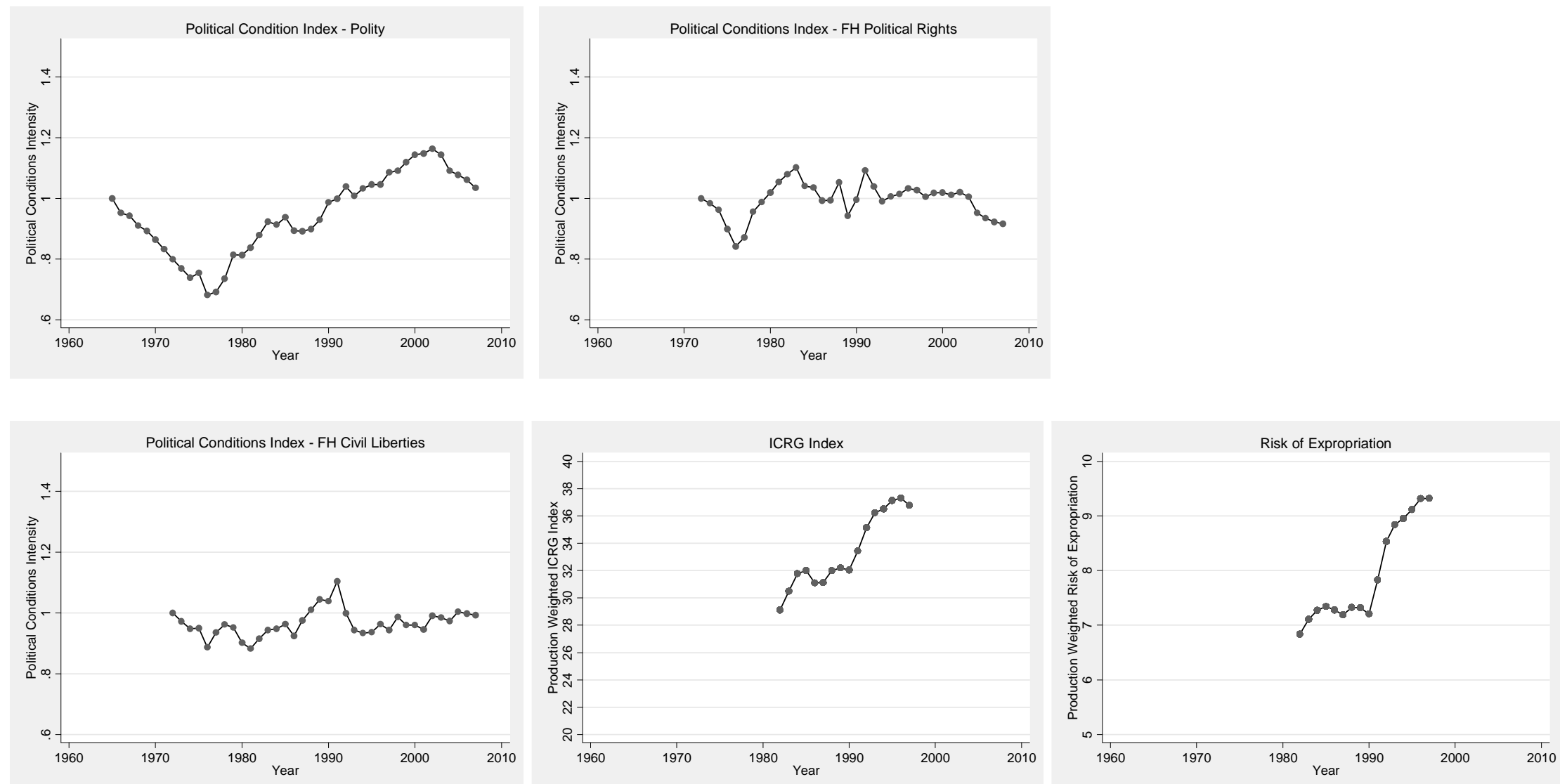

35 


\section{Figure 3. Political Conditions Index Decompositions}
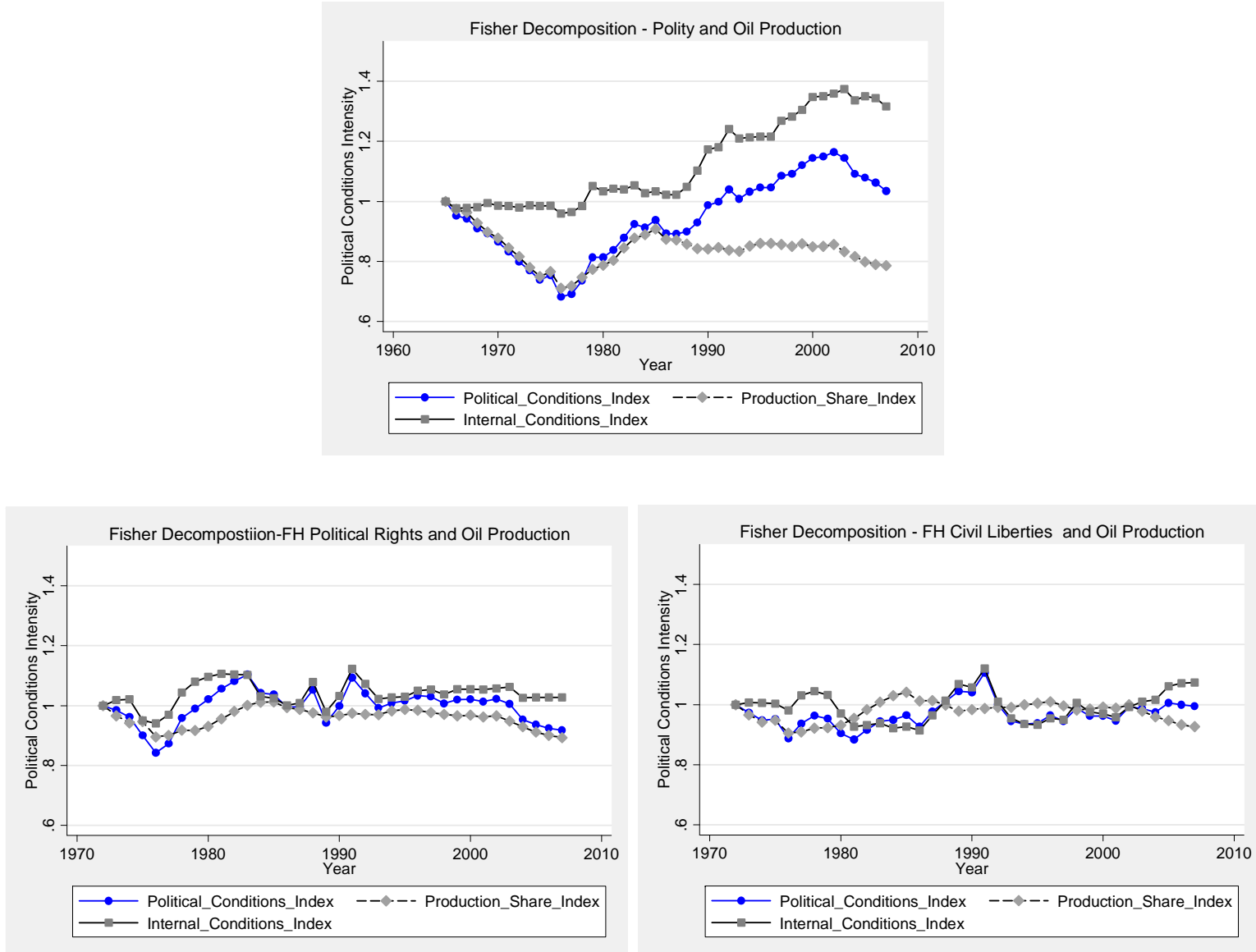


\section{Appendix (Not for Publication)}

\section{A. Construction of the Fisher Political Conditions Indexes}

We begin by constructing an index of oil security as a weighted average of country level security as measured by one of our political conditions measures weighted by oil production in that year. The index is normalized to equal one in the first year. We describe the process in detail for our polity variable.

$$
\Pi_{t}=\frac{\sum_{i} \omega_{i t} P_{i t}}{\sum_{i} \omega_{i 1965} P_{i 1965}}
$$

The political conditions index based on the polity measure $\left(P_{i t}\right)$ is denoted by $\Pi_{t}$. The numerator is the average in year $t$ of the polity measure across countries in year $t$ weighted by the share of country i's oil production in that year $\left(\omega_{i t}\right)$. To construct the Fisher Ideal index, we first construct Laspeyres and Paasche political and production indexes. The Laspeyres indexes are

$$
\begin{aligned}
L_{t}^{\text {Pol }} & =\frac{\sum_{i} \omega_{i 1965} P_{i t}}{\sum_{i} \omega_{i 1965} P_{i 1965}} \\
L_{t}^{\text {Prod }} & =\frac{\sum_{i} \omega_{i t} P_{i 1965}}{\sum_{i} \omega_{i 1965} P_{i 1965}}
\end{aligned}
$$

The Laspeyres political index fixes the oil production shares at their 1965 levels and allows the political conditions measure to change over time. It thus measures changes in the political conditions index solely due to changes within countries. The Laspeyres production index, on the contrary, measures changes in the political conditions index due to changes in each country's share of world oil production holding their political conditions constant. The Paasche indexes are

$$
\begin{aligned}
A_{t}^{\text {Pol }} & =\frac{\sum_{i} \omega_{i t} P_{i t}}{\sum_{i} \omega_{i t} P_{i 1965}} \\
A_{t}^{\text {Prod }} & =\frac{\sum_{i} \omega_{i t} P_{i t}}{\sum_{i} \omega_{i 1965} P_{i t}} .
\end{aligned}
$$


The Laspeyres indexes use a base period fixed weight while the Paasche indexes uses a period $t$ weight. The Fisher Ideal indexes are then given by

$$
\begin{aligned}
\widetilde{\Pi}_{t}^{\text {Pol }} & =\sqrt{L_{t}^{\text {Pol }} A_{t}^{\text {Pol }}} \\
\widetilde{\Pi}_{t}^{\text {Prod }} & =\sqrt{L_{t}^{\text {Prod }} A_{t}^{\text {Prod }}} .
\end{aligned}
$$

Fisher (1921) showed that his ideal index satisfied perfect decomposition of an expenditure index into a price and quantity index under conditions satisfied by our data. In our context, a Fisher ideal index provides a perfect decomposition of an aggregate political conditions index into political and production share indexes with no residual:

$$
\Pi_{t}=\widetilde{\Pi}_{t}^{\text {Pol }} \widetilde{\Pi}_{t}^{\text {Prod }} .
$$

The other political conditions indexes are decomposed in a similar fashion where we simply substitute other country level political conditions measures for the polity measure used here.

\section{B. Analysis of Large Reductions}

Section III E2 describes results of the analysis of our classification of 142 country-year observations. The observations reflect every instance in which daily average oil production dropped by more than 100,000 barrels from the previous year.

All 142 observations are listed in Appendix Table 1 below. Countries are listed in order of their largest observed reduction in our data set. In other words, Saudi Arabia is first since its reduction in 1982 of over 3 million barrels per day was the largest single year reduction in output in the world between 1965 and 2007. The "Rank" column lists the ranking by size for each individual observation.

The smallest cut reflected slightly less than a one percent reduction. The list also reflects the top 16 largest percent reductions in our data set. The largest percent reduction that we did not consider (because it reflected a cut of less than 100,000 barrels per day) was in Egypt in 1972 and reflected a 28 percent reduction as the country joined the Arab Petroleum Exporting Countries. 
For each country-year pair, we searched the business press for explanations and descriptions of oil production in the country around that time period. We classified each observation into one of the following eight categories:

Natural Disaster: We observed two instances in which natural disasters led to significant reductions in oil production. An earthquake in Ecuador in 1987 wiped out 70 kilometers of the TransEcuadorian pipeline, severely disrupting oil exports. Second, though production in the United States has been steadily declining since the early 1970s, Hurricane Katrina caused an especially large reduction in production in 2005 .

Technical Failure: Technical failures disrupted production in six instances. For example, a series of equipment failures, mechanical breakdowns and safety lapses caused production to fall precipitously in the UK's North Sea oilfields in 1988 and 1989. In June 1985, a well in Kazakhstan's Tengiz field suffered a blowout. Oil comes out of this field very hot and accompanied by gas with a high concentration of hydrogen sulfide, which is extremely poisonous. The fire burned for 6 months before firefighters could extinguish it (Pala, 2001).

High Marginal Cost of Extraction: We identified four examples of cuts in countries with high marginal extraction costs in the face of declining oil prices: two in Libya, one in Canada in the early 1980s as prices started to decline, and one in Russia (then the Soviet Union) in 1975 when the Soviet Union was a closed economy and the overall economy slowed down. The Libyan reductions could have been driven by OPEC, though the differences between low and high polity countries would be even stronger if we characterized them in the last category.

The analysis reported above in footnote 14 supports the conclusion that very little of the volatility is driven by countries adjusting marginal production in response to volatile prices. Specifically, we obtained a database of all major fields from Penwell. Offshore fields are separately identified, so we were able to develop several indicators of whether a country had only offshore fields, only onshore fields, and a rough share of total fields that are onshore. Offshore wells are considerably more expensive than onshore wells, so, if countries are reducing production from offshore fields (e.g., not developing as many new wells), production may be 
more volatile in countries with a high share of offshore fields. We found no indication of a relationship between offshore fields, however measured, and volatility.

Mature Fields: There are four countries in Appendix Table 1 whose production declines are primarily attributable to declining production from mature fields: Australia, Norway, United Kingdom and United States. North Sea oil production, which accounts for nearly all of Norwegian and UK production, peaked in 2000 and has been declining steadily since. In the United States, production has been steadily declining almost every year since 1972. Production from the two major fields in Australia, Barrow Island and Gippsland Basin, peaked in 1985, but the country was able to add new production capacity from a series of smaller fields to keep output steady until 2000 . The country's total production has been steadily declining since then (APPEO, 2011).

Nationalization: This category reflects instances in which oil production declined as the government influenced output either by nationalizing oil producing assets outright or by imposing high taxes on exporting companies. In some cases, such as Venezuela in the late 1960s and early 1970s, the nationalization process took several years and subsequent events were akin to nationalization. For instance, in 2007 when Chavez required private-sector oil companies operating in Venezuela to award PDVSA a majority share of current and subsequent projects (Gentile, 2008). Similarly, in the mid 1970s, Canada imposed high export taxes in an effort to nationalize some of the rents earned by oil producers in the face of rising world prices. Many observers attributed the subsequent decline in Canadian production to companies' decisions to reduce production in the face of the taxes (Trumbull, 1975).

Domestic Conflict: This category reflects events such as the Iranian Revolution, which included a strike by oil workers in 1978, militia attacks on oil infrastructure in the Niger Delta to protest a flawed 2007 election, and Venezuelan strikes in 2002. We characterize production declines related to the breakup of the Soviet Union as a domestic conflict.

International Conflict: This category captures supply disruptions reflecting wars, blockades, embargoes and invasion by another country. The category includes the Iran/Iraq war in 1980 and 
1981, the invasion of Kuwait and the embargo against Iraq. We opted not to characterize Saudi Arabia's cuts in the late 1970s as related to international conflict, instead characterizing that as a market power reduction.

Market Power: All observations in this category reflect OPEC member nations except for Mexico in 1986, Norway in 1998 and Mexico in 1999. Facing record low oil prices, Mexico helped broker commitments to reduce output from Venezuela, Saudi Arabia and Norway (Salpukas, 1998).

Gentile, Carmen. "Analysis: Venezuelan Oil Production Down," United Press International, January 3, 2008. Accessed at: http://www.upi.com/Business_News/EnergyResources/2008/01/03/Analysis-Venezuelan-oil-production-down/UPI35401199373331/\#ixzz1qO45v89O

Pala, Christopher. "Kazakhstan Field's Riches Come With a Price," St. Petersburg Times, October 23, 2001.

Salpukas, Agis. "Norway Pledges to Take Part in Worldwide Oil Supply Cuts," United Press International, March 31, 1998.

Trumbull, Robert. “Canada Shifts from Oil Seller to Buyer,” New York Times, August 23, 1975.

APPENDIX TABLE 1

\begin{tabular}{|c|c|c|c|c|c|}
\hline Rank & Country & Year & $\begin{array}{c}\begin{array}{c}\text { Percent } \\
\text { Reduction }\end{array} \\
\end{array}$ & $\begin{array}{c}\text { Reduction in } \\
\text { Barrels } \\
\text { ('000's per day) } \\
\end{array}$ & Reason \\
\hline 8 & Saudi Arabia & 1975 & $16 \%$ & 1402 & Market Power \\
\hline 14 & & 1978 & $9 \%$ & 865 & Market Power \\
\hline 1 & & 1982 & $32 \%$ & 3295 & Market Power \\
\hline 3 & & 1983 & $29 \%$ & 2010 & Market Power \\
\hline 40 & & 1984 & $8 \%$ & 417 & Market Power \\
\hline 11 & & 1985 & $21 \%$ & 933 & Market Power \\
\hline 27 & & 1987 & $12 \%$ & 609 & Market Power \\
\hline 119 & & 1993 & $1 \%$ & 136 & Market Power \\
\hline 23 & & 1999 & $7 \%$ & 649 & Market Power \\
\hline 54 & & 2001 & $3 \%$ & 282 & Market Power \\
\hline 55 & & 2002 & $3 \%$ & 281 & Market Power \\
\hline 60 & & 2006 & $2 \%$ & 261 & Market Power \\
\hline 39 & & 2007 & $4 \%$ & 440 & Market Power \\
\hline
\end{tabular}




\begin{tabular}{|c|c|c|c|c|c|}
\hline 21 & Iran & 1975 & $11 \%$ & 673 & Market Power \\
\hline 84 & & 1977 & $3 \%$ & 204 & Market Power \\
\hline 41 & & 1978 & $7 \%$ & 412 & Domestic Conflict \\
\hline 2 & & 1979 & $39 \%$ & 2084 & Domestic Conflict \\
\hline 6 & & 1980 & $54 \%$ & 1739 & International Conflict \\
\hline 104 & & 1981 & $11 \%$ & 158 & International Conflict \\
\hline 42 & & 1984 & $17 \%$ & 411 & International Conflict \\
\hline 109 & & 1986 & $7 \%$ & 151 & Market Power \\
\hline 64 & & 1999 & $7 \%$ & 252 & Market Power \\
\hline 65 & & 2002 & $7 \%$ & 251 & Market Power \\
\hline 102 & Iraq & 1967 & $12 \%$ & 164 & International Conflict \\
\hline 73 & & 1972 & $13 \%$ & 228 & Nationalization \\
\hline 15 & & 1980 & $24 \%$ & 831 & International Conflict \\
\hline 5 & & 1981 & $66 \%$ & 1751 & International Conflict \\
\hline 20 & & 1990 & $24 \%$ & 689 & International Conflict \\
\hline 4 & & 1991 & $87 \%$ & 1864 & International Conflict \\
\hline 43 & & 2002 & $16 \%$ & 407 & International Conflict \\
\hline 17 & & 2003 & $36 \%$ & 772 & International Conflict \\
\hline 88 & & 2005 & $10 \%$ & 197 & International Conflict \\
\hline 7 & Russia & 1975 & $20 \%$ & 1694 & High Extraction Costs \\
\hline 51 & & 1989 & $3 \%$ & 309 & Domestic Conflict \\
\hline 19 & & 1990 & $7 \%$ & 730 & Domestic Conflict \\
\hline 10 & & 1991 & $10 \%$ & 1079 & Domestic Conflict \\
\hline 9 & & 1992 & $14 \%$ & 1288 & Domestic Conflict \\
\hline 13 & & 1993 & $11 \%$ & 865 & Domestic Conflict \\
\hline 18 & & 1994 & $11 \%$ & 754 & Domestic Conflict \\
\hline 123 & & 1995 & $2 \%$ & 131 & Technical \\
\hline 96 & & 1996 & $3 \%$ & 174 & Nationalization \\
\hline 61 & Kuwait & 1973 & $8 \%$ & 259 & Market Power \\
\hline 33 & & 1974 & $15 \%$ & 477 & Nationalization \\
\hline 35 & & 1975 & $18 \%$ & 471 & Nationalization \\
\hline 95 & & 1977 & $8 \%$ & 175 & Market Power \\
\hline 12 & & 1980 & $33 \%$ & 866 & Market Power \\
\hline 30 & & 1981 & $32 \%$ & 570 & Market Power \\
\hline 49 & & 1982 & $27 \%$ & 325 & Market Power \\
\hline 138 & & 1985 & $8 \%$ & 102 & Market Power \\
\hline 117 & & 1987 & $11 \%$ & 138 & International Conflict \\
\hline 38 & & 1990 & $32 \%$ & 444 & International Conflict \\
\hline 16 & & 1991 & $81 \%$ & 779 & International Conflict \\
\hline 112 & & 1999 & $7 \%$ & 147 & Market Power \\
\hline 108 & & 2002 & $7 \%$ & 153 & Market Power \\
\hline 28 & Libya & 1971 & $18 \%$ & 607 & Market Power \\
\hline 31 & & 1972 & $18 \%$ & 502 & Market Power \\
\hline 22 & & 1974 & $30 \%$ & 653 & Market Power \\
\hline
\end{tabular}




\begin{tabular}{|c|c|c|c|c|c|}
\hline 57 & & 1980 & $13 \%$ & 277 & High Extraction Costs \\
\hline 26 & & 1981 & $33 \%$ & 609 & High Extraction Costs \\
\hline 124 & & 1984 & $11 \%$ & 129 & Market Power \\
\hline 140 & Venezuela & 1966 & $3 \%$ & 101 & Nationalization \\
\hline 116 & & 1971 & $4 \%$ & 139 & Nationalization \\
\hline 50 & & 1972 & $9 \%$ & 314 & Nationalization \\
\hline 44 & & 1974 & $11 \%$ & 395 & Nationalization \\
\hline 24 & & 1975 & $21 \%$ & 638 & Nationalization \\
\hline 87 & & 1980 & $8 \%$ & 197 & Market Power \\
\hline 79 & & 1982 & $10 \%$ & 209 & Market Power \\
\hline 139 & & 1983 & $5 \%$ & 102 & Market Power \\
\hline 133 & & 1985 & $6 \%$ & 109 & Market Power \\
\hline 45 & & 1999 & $10 \%$ & 354 & Market Power \\
\hline 67 & & 2002 & $8 \%$ & 247 & Domestic Conflict \\
\hline 47 & & 2003 & $12 \%$ & 341 & Domestic Conflict \\
\hline 126 & & 2006 & $4 \%$ & 129 & Domestic Conflict \\
\hline 89 & & 2007 & $7 \%$ & 195 & Domestic Conflict \\
\hline 94 & Nigeria & 1968 & $56 \%$ & 178 & Domestic Conflict \\
\hline 34 & & 1975 & $21 \%$ & 471 & Nationalization \\
\hline 86 & & 1978 & $10 \%$ & 201 & Market Power \\
\hline 66 & & 1980 & $11 \%$ & 247 & Market Power \\
\hline 25 & & 1981 & $30 \%$ & 619 & Market Power \\
\hline 110 & & 1982 & $10 \%$ & 150 & Market Power \\
\hline 132 & & 1987 & $8 \%$ & 114 & Market Power \\
\hline 111 & & 1998 & $6 \%$ & 149 & Market Power \\
\hline 141 & & 1999 & $5 \%$ & 101 & Domestic Conflict \\
\hline 99 & & 2002 & $8 \%$ & 171 & Domestic Conflict \\
\hline 136 & & 2006 & $4 \%$ & 106 & Domestic Conflict \\
\hline 131 & & 2007 & $5 \%$ & 118 & Domestic Conflict \\
\hline 114 & United States & 1971 & $1 \%$ & 141 & Mature Fields \\
\hline 71 & & 1973 & $2 \%$ & 239 & Mature Fields \\
\hline 32 & & 1974 & $4 \%$ & 485 & Mature Fields \\
\hline 37 & & 1975 & $4 \%$ & 453 & Mature Fields \\
\hline 58 & & 1976 & $3 \%$ & 272 & Mature Fields \\
\hline 115 & & 1979 & $1 \%$ & 138 & Mature Fields \\
\hline 46 & & 1986 & $3 \%$ & 349 & Mature Fields \\
\hline 52 & & 1987 & $3 \%$ & 287 & Mature Fields \\
\hline 93 & & 1988 & $2 \%$ & 179 & Mature Fields \\
\hline 29 & & 1989 & $6 \%$ & 606 & Technical \\
\hline 68 & & 1990 & $3 \%$ & 245 & Mature Fields \\
\hline 80 & & 1992 & $2 \%$ & 208 & Mature Fields \\
\hline 53 & & 1993 & $3 \%$ & 285 & Mature Fields \\
\hline 90 & & 1994 & $2 \%$ & 194 & Mature Fields \\
\hline 63 & & 1998 & $3 \%$ & 258 & Mature Fields \\
\hline
\end{tabular}




\begin{tabular}{|c|c|c|c|c|c|}
\hline 56 & & 1999 & $3 \%$ & 280 & Mature Fields \\
\hline 74 & & 2003 & $3 \%$ & 226 & Mature Fields \\
\hline 98 & & 2004 & $2 \%$ & 172 & Mature Fields \\
\hline 48 & & 2005 & $5 \%$ & 333 & Natural Disaster \\
\hline 85 & United Kingdom & 1988 & $8 \%$ & 197 & Technical \\
\hline 36 & & 1989 & $19 \%$ & 467 & Technical \\
\hline 70 & & 2000 & $8 \%$ & 242 & Mature Fields \\
\hline 91 & & 2001 & $7 \%$ & 191 & Mature Fields \\
\hline 81 & & 2003 & $8 \%$ & 206 & Mature Fields \\
\hline 72 & & 2004 & $10 \%$ & 229 & Mature Fields \\
\hline 77 & & 2005 & $11 \%$ & 219 & Mature Fields \\
\hline 97 & & 2006 & $10 \%$ & 173 & Mature Fields \\
\hline 59 & Indonesia & 1982 & $17 \%$ & 265 & Market Power \\
\hline 103 & & 1985 & $11 \%$ & 163 & Market Power \\
\hline 134 & & 1999 & $7 \%$ & 112 & Market Power \\
\hline 142 & & 2002 & $7 \%$ & 100 & Market Power \\
\hline 135 & & 2003 & $8 \%$ & 106 & Market Power \\
\hline 129 & Canada & 1974 & $6 \%$ & 121 & Nationalization \\
\hline 62 & & 1975 & $13 \%$ & 258 & Nationalization \\
\hline 118 & & 1976 & $8 \%$ & 137 & Nationalization \\
\hline 106 & & 1981 & $9 \%$ & 154 & High Extraction Costs \\
\hline 69 & Algeria & 1971 & $23 \%$ & 243 & Nationalization \\
\hline 120 & & 1980 & $10 \%$ & 132 & Market Power \\
\hline 113 & Norway & 1998 & $4 \%$ & 142 & Market Power \\
\hline 76 & & 2005 & $7 \%$ & 220 & Mature Fields \\
\hline 92 & & 2006 & $6 \%$ & 190 & Mature Fields \\
\hline 75 & & 2007 & $8 \%$ & 223 & Mature Fields \\
\hline 100 & United Arab Emirates & 1978 & $8 \%$ & 169 & Market Power \\
\hline 83 & & 1981 & $12 \%$ & 205 & Market Power \\
\hline 101 & & 1982 & $11 \%$ & 165 & Market Power \\
\hline 125 & & 1992 & $5 \%$ & 129 & Market Power \\
\hline 130 & & 1995 & $5 \%$ & 120 & Market Power \\
\hline 122 & & 1999 & $5 \%$ & 132 & Market Power \\
\hline 78 & & 2002 & $8 \%$ & 210 & Market Power \\
\hline 107 & Mexico & 1986 & $5 \%$ & 154 & Market Power \\
\hline 105 & & 1999 & $4 \%$ & 156 & Market Power \\
\hline 82 & & 2007 & $6 \%$ & 206 & Technical \\
\hline 121 & Kazakhstan & 1985 & $22 \%$ & 132 & Technical \\
\hline 127 & Colombia & 2000 & $15 \%$ & 127 & Domestic Conflict \\
\hline 128 & Ecuador & 1987 & $41 \%$ & 122 & Natural Disaster \\
\hline 137 & Australia & 2003 & $15 \%$ & 106 & Mature Fields \\
\hline
\end{tabular}

Sources: New York Times, Financial Times, and Wall Street Journal, multiple years. Category assignment based on authors' judgment. 